\title{
Colloid solutions for fluid resuscitation (Review)
}

\author{
Bunn F, Alderson P, Hawkins V
}

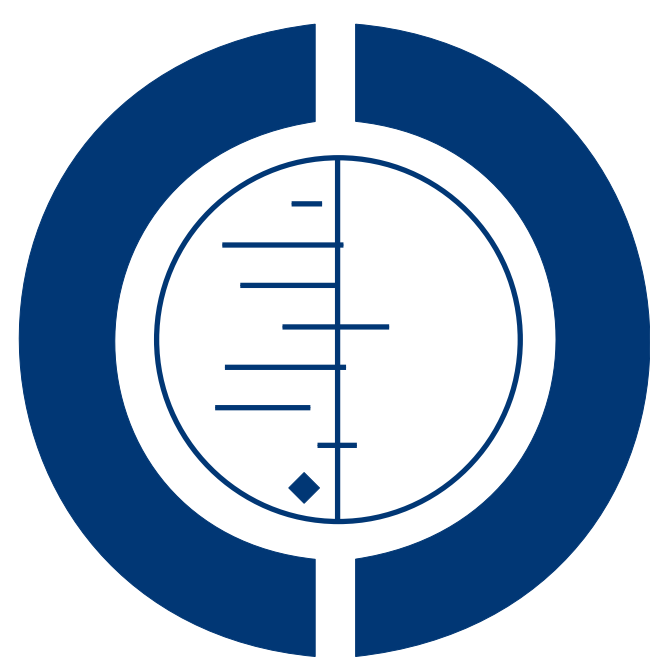

\section{THE COCHRANE COLLABORATION $^{\circledR}$}

This is a reprint of a Cochrane review, prepared and maintained by The Cochrane Collaboration and published in The Cochrane Library 2007, Issue 4

http://www.thecochranelibrary.com

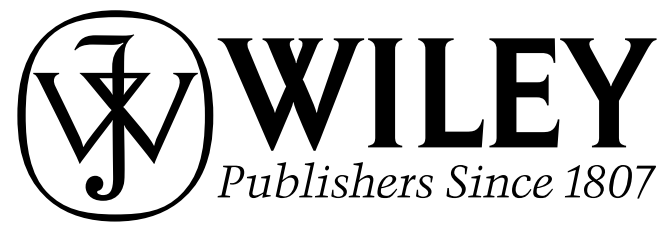

Colloid solutions for fluid resuscitation (Review)

Copyright $\odot 2007$ The Cochrane Collaboration. Published by John Wiley \& Sons, Ltd 


\section{TABLE OF CONTENTS}

ABSTRACT . . . . . . . . . . . . . . . . . . . . . . . . .

PLAIN LANGUAGE SUMMARY . . . . . . . . . . . . . . . . . . . . . . . . . . . . . . . . . . . . .

BACKGROUND . . . . . . . . . . . . . . . . . . . . . . . . . . . . . . . . . . . . . . . . 2

OBJECTIVES . . . . . . . . . . . . . . . . . . . . . . . . . . . . . . . . . . . . . . . . . . . 2

CRITERIA FOR CONSIDERING STUDIES FOR THIS REVIEW . . . . . . . . . . . . . . . . . . . . . . . . .

SEARCH METHODS FOR IDENTIFICATION OF STUDIES . . . . . . . . . . . . . . . . . . . . . . . . . 3

METHODS OF THE REVIEW . . . . . . . . . . . . . . . . . . . . . . . . . . . . . . . . . . . . . . . . . . 3

DESCRIPTION OF STUDIES . . . . . . . . . . . . . . . . . . . . . . . . . . . . . . . . . . . . . . . . . 4

METHODOLOGICAL QUALITY . . . . . . . . . . . . . . . . . . . . . . . . . . . . . . . . . . . . . $\quad 5$

RESULTS . . . . . . . . . . . . . . . . . . . . . . . . . . . . . . . . . . . . . . . . 5

DISCUSSION . . . . . . . . . . . . . . . . . . . . . . . . . . . . . . . . . . . . . 5

AUTHORS' CONCLUSIONS . . . . . . . . . . . . . . . . . . . . . . . . . . . . . . . . . . . . . . . 5

FEEDBACK . . . . . . . . . . . . . . . . . . . . . . . . . . . . . . . . . . . . . . 6

POTENTIAL CONFLICT OF INTEREST . . . . . . . . . . . . . . . . . . . . . . . . . . . . . . . . . . . . .

ACKNOWLEDGEMENTS . . . . . . . . . . . . . . . . . . . . . . . . . . . . . . . . . . . . . . . . 6.6

SOURCES OF SUPPORT . . . . . . . . . . . . . . . . . . . . . . . . . . . . . . . . . . . . . . . . . . . . 6.6

REFERENCES . . . . . . . . . . . . . . . . . . . . . . . . . . . . . . . . . . . . . 6

TABLES . . . . . . . . . . . . . . . . . . . . . . . . . . . . . . . . . . . . . . . . . . 11

Characteristics of included studies . . . . . . . . . . . . . . . . . . . . . . . . . . . . . . . . . .

Characteristics of excluded studies . . . . . . . . . . . . . . . . . . . . . . . . . . . . . . . . . . . .

ANALYSES . . . . . . . . . . . . . . . . . . . . . . . . . . . . . . . . . . . . . . . . . .

Comparison 01. Albumin or PPF vs Hydroxyethyl Starch . . . . . . . . . . . . . . . . . . . . . . . . . . . . . 31

Comparison 02. Albumin or PPF vs Gelatin . . . . . . . . . . . . . . . . . . . . . . . . . . . . . . . 31

Comparison 03. Albumin or PPF vs Dextran . . . . . . . . . . . . . . . . . . . . . . . . . . . . . . . 31

Comparison 04. Modified Gelatin vs Hydroxyethyl starch . . . . . . . . . . . . . . . . . . . . . . . . 32

Comparison 05. Modified Gelatin vs Dextran . . . . . . . . . . . . . . . . . . . . . . . . . 32

Comparison 06. Hydroxyethyl starch vs Dextran . . . . . . . . . . . . . . . . . . . . . . . . . . . . . . 32

INDEX TERMS . . . . . . . . . . . . . . . . . . . . . . . . . . . . . . . . . . . . 32

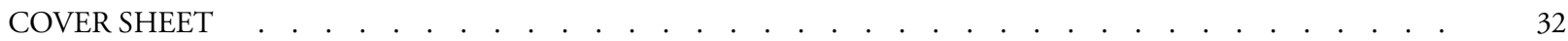

GRAPHS AND OTHER TABLES . . . . . . . . . . . . . . . . . . . . . . . . . . . . . . . . . . . . . . . . . . . . . .

Analysis 01.01. Comparison 01 Albumin or PPF vs Hydroxyethyl Starch, Outcome 01 Death . . . . . . . . . 34

Analysis 01.02. Comparison 01 Albumin or PPF vs Hydroxyethyl Starch, Outcome 02 Blood/red cells transfused 34

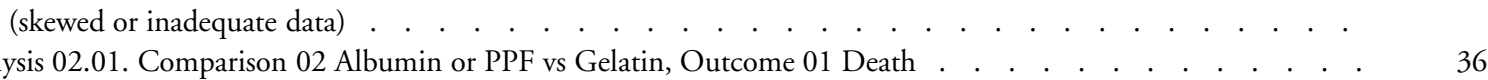

Analysis 02.01. Comparison 02 Albumin or PPF vs Gelatin, Outcome 01 Death . . . . . . . . . . . . . . . . . . . 36
Analysis 02.02. Comparison 02 Albumin or PPF vs Gelatin, Outcome 02 Blood/red cells transfused (skewed or $\quad 36$ inadequate data)

Analysis 03.01. Comparison 03 Albumin or PPF vs Dextran, Outcome 01 Death $\quad$. . . . . . . . . . . . . . . $\quad$. 37

Analysis 03.02. Comparison 03 Albumin or PPF vs Dextran, Outcome 02 Blood/red cells transfused (skewed or 37 inadequate data) . . . . . . . . . . . . . . . . . . . . . . . . . . . . . . . . . . . . . . .

Analysis 04.01. Comparison 04 Modified Gelatin vs Hydroxyethyl starch, Outcome 01 Death . . . . . . . . . 38

Analysis 04.02. Comparison 04 Modified Gelatin vs Hydroxyethyl starch, Outcome $02 \mathrm{Blood} / \mathrm{red}$ cells transfused 38 (skewed or inadequate data)

Analysis 05.01. Comparison 05 Modified Gelatin vs Dextran, Outcome 01 Death ......... . . . 39

Analysis 05.02. Comparison 05 Modified Gelatin vs Dextran, Outcome 02 Blood/red cells transfused (skewed or 40 inadequate data) . . . . . . . . . . . . . . . . . . . . . . . . . . . . . . . . . . . . . . . . . .

Analysis 06.02. Comparison 06 Hydroxyethyl starch vs Dextran, Outcome 02 Blood/red cells transfused (skewed or inadequate data) .

Colloid solutions for fluid resuscitation (Review)

Copyright $(2) 2007$ The Cochrane Collaboration. Published by John Wiley \& Sons, Ltd 


\title{
Colloid solutions for fluid resuscitation (Review)
}

\author{
Bunn F, Alderson P, Hawkins V
}

Status: Commented

This record should be cited as:

Bunn F, Alderson P, Hawkins V. Colloid solutions for fluid resuscitation. Cochrane Database of Systematic Reviews 2003, Issue 1. Art. No.: CD001319. DOI: 10.1002/14651858.CD001319.

This version first published online: 20 January 2003 in Issue 1, 2003.

Date of most recent substantive amendment: 17 September 2002

\section{A B S T R A C T}

\section{Background}

Colloids are widely used in the replacement of fluid volume. However doubts remain as to which colloid is best. Different colloids vary in their molecular weight and therefore in the length of time they remain in the circulatory system. Because of this and their other characteristics, they may differ in their safety and efficacy.

\section{Objectives}

To compare the effects of different colloid solutions in patients thought to need volume replacement.

\section{Search strategy}

We searched the Cochrane Injuries Group specialised register, the Cochrane Controlled Trials Register (2002 Issue 3), MEDLINE (1994-2002/07), EMBASE (1974-2002 August week 1), and the National Research Register (2002 issue 3). Bibliographies of trials retrieved were searched, and drug companies manufacturing colloids were contacted for information. The search was last updated in September 2002.

\section{Selection criteria}

Randomised and quasi-randomised trials comparing colloid solutions in critically ill and surgical patients thought to need volume replacement. The main outcomes measured were death, amount of whole blood transfused, and incidence of adverse reactions.

\section{Data collection and analysis}

Two authors independently extracted the data and assessed the quality of the trials.

\section{Main results}

Fifty-seven trials met the inclusion criteria, with a total of 3659 participants. Quality of allocation concealment was judged to be adequate in 20 trials and poor or uncertain in 37.

Deaths were obtained from 36 trials. For albumin or PPF versus hydroxyethyl starch (HES) 20 trials $(\mathrm{n}=1029)$ reported mortality. The pooled relative risk (RR) was 1.17 (95\% CI 0.91, 1.50). For albumin or PPF versus gelatin four trials $(\mathrm{n}=542)$ reported mortality. The $\mathrm{RR}$ was $0.99(0.69,1.42)$. For gelatin vs HES 11 trials $(\mathrm{n}=945)$ reported mortality, RR was $1.00(0.78,1.28)$. RR was not estimable in the albumin vs dextran, gelatin vs dextran, and HES vs dextran groups.

Thirty-six trials recorded the amount of blood transfused, however quantitative analysis was not possible due to skewness and variable reporting. Fifteen trials recorded adverse reactions, but none occurred.

\section{Authors' conclusions}

From this review, there is no evidence that one colloid solution is more effective or safe than any other, although the confidence intervals are wide and do not exclude clinically significant differences between colloids. Larger trials of fluid therapy are needed if clinically significant differences in mortality are to be detected or excluded. 


\section{PLAIN LANGUAGE SUMMARY}

No strong evidence to be certain of the safety of any particular type of colloid solution for replacing blood fluids

When a person is bleeding heavily, the loss of fluid volume in their veins can lead to shock, so they need fluid resuscitation. Colloids and crystalloids are two types of solutions used to replace lost blood fluid (plasma). They include blood and synthetic products. Both types appear to be similarly effective at resuscitation, but one type of colloid (human albumin) was found by another Cochrane review to increase deaths. Different colloids may have different effects. However, the review of trials found there is not enough evidence to be sure that any particular colloid is safer than any other

\section{B A C K G R O U N D}

Colloids are used as plasma substitutes for short-term replacement of fluid volume, while the cause of the problem is being addressed (e.g. stopping bleeding). These solutions can be blood products (human albumin solution, plasma protein fraction [PPF]) or synthetic (modified gelatins, dextrans, etherified starches). Colloid solutions are widely used in fluid resuscitation (Yim 1995) and they have been recommended in a number of resuscitation guidelines and intensive care management algorithms (Armstrong 1994; Vermeulen 1995). Previous systematic reviews have suggested that colloids are no more effective than crystalloids in reducing mortality (Schierhout 2000), and that albumin administration may increase mortality compared to crystalloids or no fluid in a range of uses (CIGAR 2000). Despite this, colloid solutions are still widely used as they are thought to remain in the intravascular space for longer than crystalloids and, therefore, be more effective in maintaining osmotic pressure.

It is plausible that colloids may vary in their safety and effectiveness. Different colloids vary in the length of time they remain in the circulatory system. It may be that some low to medium molecular weight colloids (e.g. gelatins and albumin) are more likely to leak into the interstitial space (Traylor 1996), whereas some larger molecular weight hydroxyethyl starches are retained for longer (Boldt 1996). In addition it is thought that some colloids may effect coagulation or cause other adverse effects.

The previous review of colloids against crystalloids only allows indirect comparison of the different colloids. This review examines direct comparisons of the different colloid solutions in randomised trials to complement the earlier reviews on colloids compared to crystalloids (Schierhout 2000) and human albumin (CIGAR 2000).

\section{O B J E C T IVES}

To quantify the relative effects on mortality of different colloid solutions in critically ill and surgical patients requiring volume replacement, by examining direct comparisons of colloid solutions.

\section{CRITERIA FOR CONSIDERING STUDIES FOR THIS REVIEW}

\section{Types of studies}

Randomised and quasi-randomised (e.g. allocation by hospital number or alternation) controlled trials.

\section{Types of participants}

Patients clinically assessed as requiring volume replacement or maintenance of colloid osmotic pressure. Administration of fluid for preoperative haemodilution or volume loading, during plasma exchange, for priming extracorporeal circuits or following paracentesis are excluded.

\section{Types of intervention}

The colloid solutions considered are human albumin solutions, plasma protein fraction, modified gelatins, dextran 70, or etherified starch solutions.

Trials of other blood products not used primarily for volume replacement (e.g. fresh frozen plasma, pooled serum) were excluded.

The review compares the administration of any regimens of different classes of colloids with each other.

\section{Types of outcome measures}

The primary outcome measure is mortality from any cause at the end of the study period. We also attempted to find data on incidence of adverse reactions, allergies or anaphylactic shock, and the amount of blood (whole blood or red blood cells) transfused in each group. Some of the synthetic colloids may have anticoagulant properties and, therefore, we felt that some measure of blood loss or haemorrhage was important. However, as blood loss is too vulnerable to measurement error, we decided to use the amount of blood products transfused as an outcome measure.

Intermediate physiological outcomes were not used for several reasons. These were that they are subject to intra- and inter-observer variation, they have no face value to patients and relatives, and the ones seen as appropriate are not stable over time. Also there would need to exist a strong predictive relationship between the variable and mortality. 


\section{SEARCH METHODS FOR IDENTIFICATIONOF STUDIES}

See: Cochrane Injuries Group methods used in reviews.

We searched the Cochrane Injuries Group trials register, the Cochrane Controlled Trials Register (2002 Issue 3), MEDLINE (1966-2002/07), and EMBASE (1974-2002 August week 1). Bibliographies of trials retrieved were searched, and drug companies manufacturing colloids were contacted for information. The search was last updated in September 2002. Search strategies for each database are given below.

Cochrane Injuries Group Trials Register:

\#1 albumin* or hypoalbumin* or plasma* or volume* or starch* or dextran* or gelofus* or haemacc* or hemacc* or colloid*.

Cochrane Controlled Trials Register (CD, 2002 issue 3):

\#1 explode "Albumins" / all SUBHEADINGS

\#2 explode "Plasma" / all SUBHEADINGS

\#3 explode "Plasma-Substitutes" / all SUBHEADINGS

\#4 (volume next replac*) or (human next albumin*)

\#5 (frozen next plasma) or (fresh next plasma)

\#6 plasma next protein*

\#7 (low next albumin*) or hypoalbumin*

\#8 starch or dextran* or gelofus* or haemacc* or hemacc*

$\# 9$ colloid or colloids

$\# 10 \# 1$ or $\# 2$ or $\# 3$ or $\# 4$ or $\# 5$ or $\# 6$ or $\# 7$ or $\# 8$ or $\# 9$.

MEDLINE (Silverplatter, 1966-2002/07):

\#1 explode "Albumins" / all SUBHEADINGS

\#2 explode "Plasma" / all SUBHEADINGS

\#3 explode "Plasma-Substitutes" / all SUBHEADINGS

\#4 (volume next replac*) or (human next albumin*)

\#5 (frozen next plasma) or (fresh next plasma)

\#6 plasma next protein*

\#7 (low next albumin*) or hypoalbumin*

\#8 starch or dextran* or gelofus* or haemacc* or hemacc*

$\# 9$ colloid or colloids

$\# 10 \# 1$ or $\# 2$ or $\# 3$ or $\# 4$ or $\# 5$ or \#6 or \#7 or \#8 or \#9

$\# 11$ \#10 and (optimally sensitive MEDLINE search strategy for identifying randomised controlled trials) (Clarke 2001).

EMBASE (Ovid, 1974-2002 Aug week 1):

\#1 exp ALBUMIN/

\#2 exp PLASMA/

\#3 exp Plasma Substitute/

\#4 volume adj replac\$

\#5 human adj albumin\$

\#6 (frozen adj plasma) or (fresh adj plasma)

\#7 plasma adj protein\$

\#8 hypoalbumin\$ or (low adj albumin)

$\# 9$ starch or dextran \$ or gelofus\$ or haemacc\$ or hemacc\$

$\# 10 \# 1$ or \#2 or \#3 or \#4 or \#5 or \#6 or \#7 or \#8 or \#9

\#11 Randomized Controlled Trial/ (25290)
\#12 randomi\$ or double blind\$ or single blind\$

\#13 \#11 or \#12

$\# 14 \# 10$ and \#13.

National Research Register (CD, 2002 issue 3):

As MEDLINE.

Trials were also identified using searches done for an earlier review of colloids vs crystalloids (Schierhout 2000), which included BIDS Index to Scientific and Technical Proceedings, drawing on the handsearching of 29 international journals and the proceedings of several international meetings on fluid resuscitation, and checking the reference lists of the trials found.

To identify unpublished trials we searched the UK National Research Register, the register of the Medical Editors' Trial Amnesty, on the Cochrane Library, and we contacted the UK Medicines Control Agency. We also contacted the medical directors of the following companies who all manufacture colloids: Alpha Therapeutic UK Limited (Albutein), American Critical Care McGraw (Hespan), Bayer (Plasbumin), Baxter (Gentran), Bio Products Laboratory (Zenalb), Cambridge Laboratories (Rheomacrodex), Centeon Limited (Albuminar), CIS UK Ltd , CP (Lomodex), Common Services Agency, Consolidated (Gelofusine), DuPont (Hespan) Fresenius (eloHAES and HAES-Steril), Geistlich Sons Ltd (Hespan and Pentaspan), Hoechst (Haemaccel), Mallinckrodt Medical GMBH (Infoson), Nycomed, Oxford Nutrition (Elohes), Pharmacia and Upjohn Ltd (Rheomacrodex), and Sorin Biomedica Diagnostics Spa.

There were no language restrictions in any of the searches.

\section{METHODSOF THEREVIEW}

\section{Trial identification}

One reviewer examined the electronic search results for reports of possibly relevant trials and these reports were then retrieved in full. Two reviewers (PA and FB) applied the selection criteria independently to the trial reports, resolving disagreements by discussion.

\section{Quality assessment}

Since there is evidence that the quality of allocation concealment particularly affects the results of studies (Schulz 1995), two reviewers scored this quality on the scale used by Schulz (Schulz 1995) as shown below, assigning $C$ to poorest quality and A to best quality:

$\mathrm{A}=$ trials deemed to have taken adequate measures to conceal allocation (i.e. central randomisation; numbered or coded bottles or containers; drugs prepared by the pharmacy; serially numbered, opaque, sealed envelopes; or other description that contained elements convincing of concealment). 
$\mathrm{B}=$ trials in which the authors either did not report an allocation concealment approach at all or reported an approach that did not fall into one of the other categories.

$\mathrm{C}=$ trials in which concealment was inadequate (such as alternation or reference to case record numbers or to dates of birth)

Where the method used to conceal allocation was not clearly reported, the author was contacted, if possible, for clarification. We then compared the scores allocated and resolved differences by discussion.

\section{Data extraction}

Two reviewers independently extracted information on the following: method of allocation concealment, number of randomised patients, type of participants and the interventions. The outcome data sought were numbers of deaths, volume of blood transfused, and incidence of adverse or allergic reactions. The reviewers were not blinded to the authors or journal when doing this, as the value of this has not been established (Berlin 1997). Results were compared and any differences resolved by discussion.

Where there was insufficient information in the published report, we attempted to contact the authors for clarification.

Analysis

The following comparisons were made:

- albumin or PPF vs etherified starch

- albumin or PPF vs modified gelatin

- albumin or PPF vs dextran 70

- modified gelatin vs etherified starch

- modified gelatin vs dextran 70

- etherified starch vs dextran 70 .

For each trial the relative risk of death and $95 \%$ confidence interval was calculated, such that a relative risk of more than 1 indicates a higher risk of death in the first group named. Relative risk was chosen as a measure, as it is more readily applied to the clinical situation.

The groups of trials were examined for statistical evidence of heterogeneity using a chi-square test. If there was no obvious heterogeneity on visual inspection or statistical testing, pooled relative risks and $95 \%$ confidence intervals were calculated using a fixed-effects model.

We assessed the skewness of continuous data by checking the mean and standard deviation (if available). If the standard deviation is more than twice the mean for data with a finite end point (such as 0 in the case of bleeding), the data are likely to be skewed and it is inappropriate to apply parametric tests (Altman 1996). This is because the mean is unlikely to be a good measure of central tendency. If parametric tests could not be applied, we tabulated the data.
The effect of excluding trials judged to have inadequate (scoring C) allocation concealment were examined in a sensitivity analysis.

\section{DESCRIPTIONOF STUDIES}

For more detailed descriptions of individual studies, please see the table of included studies.

A total of 57 trials met the inclusion criteria, with a total of 3659 participants. The earliest trial was from 1980 and the most recent from 2001. From the drug companies we contacted, we were sent information by Hoechst, Baxter Health Care Ltd, Fresenius Ltd, CIS UK Ltd, and Rhemoacrodex. No new trials were identified from the information sent to us.

The trials included the following comparisons:

Albumin or PPF vs starch ( $\mathrm{n}=35$ trials with 1482 participants in these groups)

Boldt 1986, Boldt 1996A, Boldt 1996B, Boldt 1996C, Boldt 1993, Boldt 1995, Boldt 1998, Brock 1995, Brutocao 1996, Claes 1992, Diehl 1982, Falk 1988, Fulachier 1994, Gahr 1981, Gallagher 1985, Gold 1990, Hausdorfer 1986, Hippala 1995, Huskisson 1993, Kirklin 1984, London 1989, Munsch 1988, Munoz 1980, Moggio 1983, Mastroianni 1994, Prien 1990, Rosencher 1992, Rackow 1983, Rackow 1989, Shatney 1983, Vogt 1994, Vogt 1996, Vogt 1999, Von Sommoggy 1990, Woittiez 1997.

Albumin or PPF vs dextran ( $\mathrm{n}=5$ trials with 390 participants in these groups):

Hedstrand 1987, Hippala 1995, Karanko 1987, Lisander 1996, Tollosfrud 1995

Albumin or PPF vs gelatin ( $\mathrm{n}=13$ trials with 997 participants in these groups):

Boldt 1986, Du Gres 1989, Huskisson 1993, Karanko 1987, Stockwell 1992, Stoddart 1996, Tollosfrud 1995, Wahba 1996.

Starch vs gelatin ( $\mathrm{n}=15$ trials with 848 participants in these groups):

Allison 1999, Asfar 2000, Beards 1994, Berard 1995, Beyer 1997, Boldt 1986, Boldt 2000, Boldt 2001, Carli 2000, Dytkowska, Haisch 2001a, Haisch 2001b, Huskisson 1993, Huttner 2000, Schortgen 2001.

Starch vs dextran ( $\mathrm{n}=1$ trial with 30 participants in these groups): Hippala 1995.

Dextran vs gelatin ( $\mathrm{n}=2$ trial with 42 participants in these groups): Karanko 1987, Tollosfrud 1995.

The trials included patients with hypovolaemia, sepsis, trauma, and patients who had undergone surgery.

The trials tended to report surrogate outcomes such as hemodynamic variables. Data on death were obtainable from only 31 of 
the trials. Information on the amount of blood transfused was available in 31 of the trials. However this was reported in a variety of different ways that made combining the data in a meta-analysis unfeasible.

Inclusion and exclusion criteria varied, but many of the studies excluded patients with previous adverse reactions to colloids, clotting problems, or renal disease.

\section{METHODOLOGICAL QUALITY}

Using predefined criteria (Schulz 1995) the quality of allocation concealment was judged to be adequate in 20 trials, unclear in 29 trials and inadequate in eight trials. Where the method of allocation concealment was unclear, we attempted to contact all of the trialists and we obtained information from 11 of them. However, due to the lack of reported information on the process of randomisation and allocation concealment, we were unable to properly assess the quality of the majority of the trials. Ten trials mentioned blinding. In four of these those giving the treatment were blinded, in four those giving post-operative care and were blinded and in the other two trials the outcome assessors were blinded.

\section{R E S U L T S}

Of the 57 trials identified 24 reported mortality data. Information on death was obtained from a further 12 trials by contact with the authors. We therefore had data on death from 36 trials.

Albumin or PPF vs starch:

Twenty trials (1029 participants) reported mortality data. The pooled relative risk was 1.17 (95\% CI 0.91-1.50).

Albumin or PPF vs gelatin:

Four trials (542 participants) reported mortality but only one of those trials had any deaths. The relative risk was 0.99 (95\% CI $0.69-1.42)$.

Albumin or PPF vs dextran:

Three trials reported mortality and were included in the metaanalysis. There were no deaths so relative risk was not estimable.

Gelatin vs starch:

Eleven trials ( 945 participants) reported mortality and the pooled relative risk was 1.00 (95\% CI 0.78-1.28).

Gelatin vs dextran 70

There were two trials which reported mortality. There were no deaths so the relative risk was not estimable.

Hydroxyethyl starch vs dextran 70 :

No trials reported mortality.

Thirty-five trials recorded the amount of blood transfused. As the data was reported in various ways, often lacking a measure of variation, and was also skewed we did not attempt a quantitative synthesis. This data can be seen in the "other data" table. Fifteen trials reported the incidence of adverse or allergic reactions or anaphylactic shock: all reported that there were no such incidents.

The effect of excluding trials judged to have inadequate (scoring C) allocation concealment was examined in a sub-group analysis. This made no significant difference to the results.

\section{DISCUSSION}

Despite finding 57 trials we cannot make any conclusions about the relative effectiveness of different colloid solutions. A previous review suggested that albumin may increase mortality in critically ill patients (CIGAR 2000), but there are too few data available to show in direct comparisons whether the synthetic alternatives are safer. The confidence intervals are wide and do not exclude clinically significant differences between colloids.

Mortality was selected as the main outcome measure in this systematic review for several reasons. In the context of critical illness, death or survival is a clinically relevant outcome that is of immediate importance to patients, and data on death are reported in many of the studies. Furthermore, one might expect that mortality data would be less prone to measurement error or biased reporting than would data on pathophysiological outcomes. The use of a pathophysiological end point as a surrogate for an adverse outcome assumes a direct relationship between the two, an assumption that may sometimes be inappropriate. Finally, when trials collect data on a number of physiological end-points, there is the potential for bias due to the selective publication of endpoints showing striking treatment effects.

There was wide variation in the participants, intervention regimens, and the length of follow-up. The length of follow-up is not reported in many of the studies. Where it is reported it ranges from a matter of hours to months, which may explain a lot of the heterogeneity in overall event rates. The effect of these factors was not examined in a sensitivity analysis, as there was felt to be insufficient data to justify examining subgroups.

Many of the trials were small, and some had been done some time ago. Although older trials will not necessarily be of poorer quality, it may be that treatment protocols have subsequently altered making these trials less relevant to current clinical practice.

\section{A U THORS, CONCLUSIONS}

\section{Implications for practice}

Previous reviews have failed to show any benefit of colloids over crystalloids for volume replacement (Schierhout 2000) and suggested that albumin solution may increase mortality in critically ill patients (CIGAR 2000). 
This review does not provide any evidence that one colloid is safer than another, but does not rule out clinically significant differences.

\section{Implications for research}

Trials of fluid therapy need to be larger in order to exclude clinically significant differences between colloids in patient relevant outcomes. However, trials should probably first address the question of whether colloids are any more effective than crystalloid solutions.

Use of surrogate outcomes, such as physiological measurements should be discouraged unless there is a strong relationship with outcomes of interest to patients and relatives.

\section{F E E D B A C K}

\section{Colloid solutions for fluid resuscitation}

Summary

1. Please explain, in the 'what's new' section, in what respects this update differs from the previous version.

2. The drug companies listed in the acknowledgments are not in alphabetic order: please do so or explain the reason for the order shown (e.g. in order of helpfulness).

3. Fresenius is misspelt

4. In the references to included trials, please use an asterisk to identify those trials which are the main publication where there are more than one article referring to a trial.

Author's reply

1. The review has been marked as an update by mistake. As of September 1999 no substantial updates have been made.
2. The drug companies have been re-ordered alphabetically. 3. The spelling of Fresenius is corrected.

4. The primary reference has been marked with an asterisk.

Contributors

Comment by Andrew Herxheimer

Response by Frances Bunn

\section{POTENTIAL CONFLICTOF I N T ER ES T}

None known.

\section{ACKNOWLEDGEMENTS}

We wish to acknowledge the help of Ralph Bloch, Olivier Duperrex, Andrew Smith, Peter Smith and Reinhard Wentz, who assisted with translating articles. Also many thanks to the authors who provided us with details of their studies.

We are grateful to the drug companies, Baxter Healthcare Ltd, CIS Ltd, Fresenius, Hoechst, and Pharmalink who responded to our request for information.

\section{SOURCES OF SUPPORT}

\section{External sources of support}

- NHS Research and Development Programme UK

Internal sources of support

- University of Hertfordshire UK

\section{REFER E NCES}

\author{
References to studies included in this review \\ Allison 1999 \{published data only\} \\ Allison KP, Gosling P, Jones S, Pallister I, Porter K. Randomized \\ trial of hydroxyethyl starch versus gelatine for trauma resuscitation. \\ Journal of Trauma 1999;47(6):1114-1121. \\ Asfar 2000 \{published data only\} \\ Asfar P, Kereni N, Labadie F, Gouello JP, Brenet O, Alquier P. As- \\ sessment of hemodynamic and gastric mucosal acidosis with modi- \\ fied fluid versus $6 \%$ hydroxyethyl starch: a prospective, randomized \\ study. Intensive Care Medicine 2000;26(9):1282-1287. \\ Beards 1994 \{published and unpublished data\} \\ Beards SC, Watt T, Edwards JD, Nightingale P, Farragher EB. Com- \\ parison of the hemodynamic and oxygen transport responses to mod- \\ ified fluid gelatin and hetastarch in critically ill patients: a prospective, \\ randomized trial. Critical care medicine 1994;22(4):600-5. [Med- \\ Line: 1994192356 ].
}

Berard 1995 \{published data only\} Berard J-P, Curt I, Piech J-J, Ruiz F. Hydroxyethylamidons versus gelatines: impact on the cost of replacement in an emergency (resuscitation) service [Hydroxyethylamidons versus gelatines: Impact sur le cout du rempissage dans un service de reanimation]. Annales Francaises d'Anaesthesia et de Reanimation 1995;14:R335.

Beyer 1997 \{published and unpublished data\} Beyer R, Harmening U, Rittmeyer O, Zielmann S, Mielck F, Kazmaier S, Kettler D. Use of modified fluid gelatin and hydroxyethyl starch for colloidal volume replacement in major orthopaedic surgery. British Journal of Anaesthesia 1997;78(1):44-50. [MedLine: 1997212347]

Boldt 1986 \{published data only\} Boldt JV, Von Bormann B, Kling D, Borner U, Mulch J, Hempelmann G. Volume replacement with a new hydroxyethyl starch preparation (3\% HES 200/0.5) in heart surgery [Volumenersatz mit 
einem neuen hydroxyathylstarke - praparat (3\% HAS 200/0.5) in der herzchirurgie]. Infusionstherapie und Klinische Ernahrung 1986; 13(3):145-151. [MedLine: 1986302988].

Boldt 1993 A \{published and unpublished data\}

Boldt J, Knothe C, Zickmann B, Andres P, Dapper F, Hempelmann G. Influence of different intravascular volume therapies on platelet function in patients undergoing cardiopulmonary bypass. Anesthesia and Analgesia 1993;76(6):1185-90.

Boldt 1995 \{published data only\}

Boldt J, Heesen M, Welters I, Padberg W, Martin K, Hempelmann G. Does the type of volume therapy influence endothelial-related coagulation in the critically ill?. British Journal of Anaesthesia 1995; 75(6):740-746. [MedLine: 1996246804].

Boldt 1996 A \{published data only\}

Boldt J, Heesen M, Muller M, Pabsdorf M, Hempelmann G. The effects of albumin versus hydroxyethyl starch solution on cardiorespiratory and circulatory variables in critically ill patients. Anesthesia and Analgesia 1996;83(2):254-61. [MedLine: 1996302067].

Boldt 1996 B \{published data only\}

Boldt J, Heesen M, Padberg W, Martin K, Hempelmann G. The influence of volume therapy and pentoxifylline infusion on circulating adhesion molecules in trauma patients. Anaesthesia 1996;51(6): 529-535. [MedLine: 1996296856].

Boldt 1996 C \{published data only\}

Boldt J, Mueller M, Menges T, Papsdorf M, Hempelmann G. Influence of different volume therapy regimens on regulators of the circulation in the critically ill. British Journal of Anaesthesia 1996;77 (4):480-487. [MedLine: 1997097789].

Boldt 1998 \{published data only\}

Boldt J, Muller M, Mentges D, Papsdorf M, Hempelmann G. Volume therapy in the critically ill: is there a difference?. Intensive Care Medicine 1998;24(1):28-36. [MedLine: 1998163949].

Boldt 2000 \{published data only\}

Boldt J, Suttner S, Kumle B, Huttner I. Cost analysis of different volume replacement strategies in anesthesia. Infusionstherapie und Transfusionsmedizin 2000;27(1):38-43.

Boldt 2001 \{published data only\}

Boldt J, Suttner S, Huttner I, Kumle B, Piper S, Krumholz W. Are cost of a crystalloid-based volume replacement regimen lower than of a colloid-based volume replacement strategy?. Infusionstherapie und transfusionsmedizin 2001;28(3):144-149.

Brock 1995 \{published and unpublished data\} Brock H, Rapf B, Necek S, Gabriel C, Peterlik C, Polz W. Volume replacement after cardiac surgery. A comparison of small-volume resuscitation and two different colloid solutions [Vergleichende untersuchungen zur postoperativen volumentherapie]. Anaesthesist 1995; 44(7):486-492. [MedLine: 1995390424].

Brutocao 1996 \{published and unpublished data\} Brutocao D, Bratton SL, Thomas JR, Schrader PF, Coles PG, Lynn AM. Comparison of hetastarch with albumin for postoperative volume expansion in children after cardiopulmonary bypass. Journal of Cardiothoracic and Vascular Anesthesia 1996;10(3):348-351. [MedLine: 1996298754].
Carli 2000 \{published data only\}

Carli P, Goldstein P, Lejay M, Facon A, Orliaguet G, Petit P. Prehospital care of hypovolemic trauma patients: $6 \%$ hydroxyethyl starch versus gelatin [Remplissage vasculaire prehospitalier en traumatologie: Hesteril 6\% versus Plasmion]. Journal Europeen des Urgences 2000; 13(1-2):101-105.

Claes 1992 \{published data only\}

Claes Y, Van Hemelrijck J, Van Gerven M, Arnout J, Vermylen J, Weidler B, Van Aken H. Influence of hydroxyethyl starch on coagulation in patients during the perioperative period. Anesthesia and Analgesia 1992;75(1):24-30. [MedLine: 1992312872].

Diehl 1982 \{published data only\}

Diehl JT, Lester JL, Cosgrove DM. Clinical comparison of hetastarch and albumin in postoperative cardiac patients. Annals of Thoracic Surgery 1982;34(6):674-679. [MedLine: 1983073643].

Du Gres 1989 \{published data only\}

Du Gres B, Gruner MC, Flamens C. A comparison of the hemodynamic effect of Haemaccel and diluted albumin in the immediate postoperative period after heart surgery [Comparaison des effets hemodynamiques de l'Haemaccel et de l'albumine diluee dans la periode postoperatoire immediate apres chirurgie cardiaque]. Cahiers d'Anesthesiologie 1989;37(5):327-332. [MedLine: 1990029584].

Dytkowska 1998 \{published data only\}

Dytkowska B, Karwacki Z, Suchorzewska J, Wujtewicz M. Comparative assessment of 200/0.5 HAES $6 \%$ and Gelafundin in the treatment of hypovolaemia in post-coronary bypass patients. Medical Science Monitor 1998;4(6):1000-1003.

Falk 1988 \{published data only\}

Falk JL, Rackow EC, Astiz ME, Weil MH. Effects of hetastarch and albumin on coagulation in patients with septic shock. Journal of Clinical Pharmacololgy 1988;28(5):412-415. [MedLine: 1988273726].

Fulachier 1994 \{published data only\}

Fulachier V, Sicard MP, Baille Y, Auffray JP. Effects of fluid expansion using albumin or hydroxyethylstarch on oxygen transport after induction of anesthesia for cardiac surgery. Journal of Cardiothoracic and Vascular anesthesia 1994;8(3Supp2):89.

Gahr 1981 \{published data only\}

Gahr R, Bock PR. Effect of hydroxyethyl starch HES 450/0.7 and $5 \%$ human albumin on the colloid osmotic pressure and hemodynamic parameters in hypovolemic patients after major abdominal procedures [Wirkung von hydroxyathylstarke HAS 450/0.7 und humanalbumin 5\% auf den kolloidosmotischen druck und hamodynamische parameter bei hypovolamischen patienten nach grosseren abdominalen eingriffen]. Infusionstherapie und Transfusionsmedizin 1981;8(3):147-152. [MedLine: 1981262968].

Gallagher 1985 \{published and unpublished data\} Gallagher JD, Moore RA, Kerns D, Jose AB, Botros SB, Flicker S, Naidech H, Clark DL. Effects of colloid or crystalloid administration on pulmonary extravascular water in the postoperative period after coronary artery bypass grafting. Anesthesia and Analgesia 1985;64(8): 753-8.

Gold 1990 \{published and unpublished data\}

Gold MS, Russo J, Tissot M, Weinhouse G, Riles T. Comparison of hetastarch to albumin for perioperative bleeding in patients undergoing abdominal aortic aneurysm surgery. Annals of Surgery 1990; 211(4):482-485. [MedLine: 1990210743]. 
Haisch 2001a \{published data only\}

Haisch G, Boldt J, Krebs C, Suttner S, Lehmann A, Isgro F. Influence of a new hydroxyethylstarch preparation (HES 130/0.4) on coagulation in cardiac surgical patients. Journal of Cardiothoracic and Vascular Anesthesia 2001;15(3):316-321.

Haisch 2001b \{published data only\}

Haisch G, Boldt J, Krebs C, Kumle B, Suttner S, Schulz A. The influence of intravascular volume therapy with a new hydroxyethyl starch preparation (6\% HES 130/0.4) on coagulation in patients undergoing major abdominal surgery. Anesthesia and Analgesia 2001; 92(3):565-71. [MedLine: 21124037].

Hausdorfer 1986 \{published data only\}

Hausdorfer J, Hagemann H, Heine J. Comparison of volume substitutes human albumin 5\% and hydroxyethyl starch $6 \%$ in paediatric anaesthesia [Vergleich der volumenersatzmittel humanalbumin 5\% und hydroxathylstarke $6 \%(40.000 / 0.5)$ in der kinderanasthesie]. Anasthesie, Intensivtherapie, Notfallmedizin 1986;21(3):137142. [MedLine: 1986320933].

Hedstrand 1987 \{published data only\}

Hedstrand U, Hogman C, Zaren B, Lundkvist B. Postoperative complications after blood replacement with or without plasma. Acta chirurgica Scandinavica 1987;153(9):501-505.

Hiippala 1995 \{published data only\}

Hiippala S, Linko K, Myllyla G, Lalla M, Hekali R, Makelainen A. Replacement of major surgical blood loss by hypo-oncotic or conventional plasma substitutes. Acta Anaesthesiologia Scandinavica 1995; 39(2):228-235. [MedLine: 1995313480].

Huskisson 1993 \{published data only\}

Huskisson L, Elliott M, Spitz L. Haemodynamic effects of three colloids following pediatric open heart surgery. Clinical Intensive Care 1993;4:302.

Huttner 2000 \{published data only\}

Huttner I, Boldt J, Haisch G, Suttner S, Kumle B, Schulz H. Influence of different colloids on molecular markers of haemostasis and platelet function in patients undergoing major abdominal surgery. British Journal of Anaesthesia 2000;85(3):417-23.

Karanko 1987 \{published and unpublished data\}

Karanko MS. Effects of three colloid solutions on plasma volume and hemodynamics after coronary bypass surgery. Critical Care Medicine 1987;15(11):1015-1021. [MedLine: 1988054051].

Kirklin 1984 \{published data only\}

Kirklin JK, Lell WA, Kouchoukos NT. Hydroxyethyl starch versus albumin for colloid infusion following cardiopulmonary bypass in patients undergoing myocardial revascularization. Annals of Thoracic Surgery 1984;37(1):40-46. [MedLine: 1984103384].

Lisander 1996 \{published and unpublished data\} Lisander B, Jacobsson SA, Ivarsson I, Vegfors M, Engdahl O. Giving both enoxaparin and dextran increases the need for transfusion in revision hip arthroplasty. European Journal of Surgery 1996;162(11): 861-866. [MedLine: 1997115584].

London 1989 \{published data only\}

London MJ, Ho JS, Triedman JK, Verrier ED, Levin J, Merrick SH, et al. A randomized clinical trial of $10 \%$ pentastarch (low molecular weight hydroxyethyl starch) versus 5\% albumin for plasma volume expansion after cardiac operations. Journal of thoracic and cardiovascular surgery 1989;97(5):785-97. [MedLine: 1989218083].

Mastroianni 1994 \{published data only\}

Mastroianni L, Low HB, Rollman J, Wagle M, Bleske B, Chow MS. A comparison of $10 \%$ pentastarch and $5 \%$ albumin in patients undergoing open-heart surgery. Journal of Clinical Pharmacology 1994; 34(1):34-40. [MedLine: 1994179580].

Moggio 1983 \{published data only\}

Moggio RA, Rha CC, Somberg ED, Praeger P, Pooley RW, Reed GE. Hemodynamic comparison of albumin and hydroxyethyl starch in postoperative cardiac surgery patients. Critical Care Medicine 1983; 11(12):943-945. [MedLine: 1984056648].

Munoz 1980 \{published data only\}

Munoz E, Raciti A, Dove D, Stahl WM, Del Guercio L. Effect of hydroxyethyl starch versus albumin on hemodymanic and respiratory function in patients with shock. Critical Care Medicine 1980;8(4): 255.

Munsch 1988 \{published data only\}

Munsch CM, MacIntyre E, Machin SJ, Mackie IJ, Treasure T. Hydroxyethyl starch: an alternative to plasma for postoperative volume expansion after cardiac surgery. British Journal of surgery 1988;75(7): 675-678. [MedLine: 1988327292].

Prien 1990 \{published and unpublished data\}

Prien T, Backhaus N, Pelster F, Pircher W, Bunte H, Lawin P. Effect of intraoperative fluid administration and colloid osmotic pressure on the formation of intestinal edema during gastrointestinal surgery. Journal of Clinical Anesthesia 1990;2(5):317-23. [MedLine: 1991104037].

Rackow 1983 \{published data only\} Rackow EC, Falk JL, Fein IA, Siegel JS, Packman MI, Haupt MT, Kaufman S, Putnam D. Fluid resuscitation in circulatory shock: A comparison of the cardiorespiratory effects of albumin, hetastarch, and saline solutions in patients with hypovolemic and septic shock. Critical Care Medicine 1983;11(11):839-850. [MedLine: 1984027713].

Rackow 1989 \{published data only\}

Rackow EC, Mecher C, Astiz ME, Griffel M, Falk JL, Weil MH. Effects of pentastarch and albumin infusion on cardiorespiratory function and coagulation in patients with severe sepsis and systemic hypoperfusion. Critical Care Medicine 1989;17(5):395-398. [MedLine: 1989209912].

Rosencher 1992 \{published and unpublished data\} Rosencher N, Vassilieff N, Guigonis V, Toulin P, Conseiller C. Comparison of effects of Elohes and albumin on haemostasis in orthopedic surgery [Comparaison des effets de l'Elohes et de l'albumine sur l'hemostase en chirurgie orthopedique]. Annales francaises d'Anesthesie et de Reanimation 1992;11(5):526-530. [MedLine: 1993118965].

Schortgen 2001 \{published data only\}

Schortgen F, Lacherade J, Bruneel F, Cattaneo I, Hemery F, Lemaire F, Brochard L. Effects of hydroxyethylstarch and gelatin on renal function in severe sepsis: a multicentre randomised study. Lancet 2001;357(9260):911-916.

Shatney 1983 \{published data only\} Shatney CH, Deepika K, Militello PR, Majerus TC, Dawson RB. Efficacy of hetastarch in the resuscitation of patients with multisys- 
tem trauma and shock. Archives of Surgery 1983;118(7):804-809. [MedLine: 1983230251].

Stockwell 1992 \{published data only\}

Stockwell MA, Scott A, Day A, Riley B, Soni N. Colloid solutions in the critically ill. A randomised comparison of albumin and polygeline: 2. Serum albumin concentration and incidences of pulmonary oedema. Anesthesia 1992;47(1):7-9.

* Stockwell MA, Soni N, Riley B. Colloid solutions in the critically ill. A randomised comparison of albumin and polygeline: 1. Outcome and duration of stay in the intensive care unit. Anaesthesia 1992;47 (1):3-6. [MedLine: 1992161241].

Stoddart 1996 \{published data only\}

Stoddart PA, Rich P, Sury MR. A comparison of $4.5 \%$ human albumin solution and haemaccel in neonates undergoing major surgery. Paediatric Anaesthesia 1996;6(2):103-106. [MedLine: 1996243349].

Tollofsrud 1995 \{published data only\}

Svennevig JL, Tollofsrud S, Kongsgaard U, Noddeland H, Mohr B, Ozer M, Mollnes TE. Complement activation during and after openheart surgery is only marginally affected by the choice of fluid for volume replacement. Perfusion 1996;11(4):326-32.

* Tollofsrud S, Svennevig JL, Breivik H, Kongsgaard U, Ozer M, Hysing E, et al. Fluid balance and pulmonary functions during and after coronary artery bypass surgery: Ringer's acetate compared with dextran, polygeline, or albumin. Acta anaesthesiologica Scandinavica 1995;39(5):671-7.

Vogt 1994 \{published data only\}

Vogt N, Bothner U, Georgieff M. Comparison of 5\% human albumin and 6\% 200/0.5 HES as exclusive colloid components in large surgical interventions [Vergleich von humanalbumin 5\% und 6\% HES 200/0.5 als ausschliessliche kolloidkomponente bei grossen chirurgischen eingriffen]. Anasthesiologie, Intensivmedizin, Notfallmedizin, Schmerztherapie 1994;29(3):150-156.

Vogt 1996 \{published data only\}

Vogt NH, Bothner U, Lerch G, Linder KH, Georgieff M. Largedose administration of $6 \%$ hydroxyethyl starch $200 / 0.5$ for total hip arthroplasty: Plasma homeostasis, hemostasis, and renal function compared to use of 5\% human albumin. Anesthesia and Analgesia 1996;83(2):262-8. [MedLine: 1996302068].

Vogt 1999 \{published data only\}

* Vogt N, Bothner U, Brinkmann A, De Petriconi R, Georgieff M. Peri-operative tolerance to large-dose 6\% HES 200/0.5 in major urological procedures compared with 5\% human albumin. Anaesthesia 1999;54(2):121-127.

Vogt N, Bothner U, Lerch G, Georgieff M. [Pharmakokinetik und onkotisches verhalten von hochdosierter hydroxyathylstarke bei operativen eingriffen im vergleich zu humanalbumin 5\%]. Infusion Therapy and Transfusion Medicine 1998;25:212-221.

von Sommoggy 1990 \{published data only\}

Von Sommoggy S, Fraunhofer J, Jelen-Esselborn S, Stemberger A. Coagulation changes during aortofemural bifurcation bypass: is volume and plasma substitution possible with hydroxyethyl starch alone? [Gerinnungsveranderungen bei aortofemoralem bifurkationsbypass: ist eine Volumen -und Plasmasubstitution mit hydroxyathylstarke allein moglich?]. Anaesthesist 1990;39(7):353-360.

Wahba 1996 \{published and unpublished data\}

Wahba A, Sendtner E, Birnbaum DE. Fluid resuscitation with Haemaccel vs. human albumin following coronary artery bypass grafting. The Thoracic and Cardiovascular Surgeon 1996;44(4):178183. [MedLine: 1997051433].

Watkins 1990 \{published data only\}

Watkins J, Wild G, Appleyard TN, Hardy G. Complement activation by polystarch and gelatine volume expanders. Lancet 1990;335 (8683):233

Woittiez 1997 \{published and unpublished data\} Hondebrink Y, Jeekel L, Oude Nijhuis J, Woittiez AJJ. Restoration of colloid osmotic pressure in hypoalbuminaemic patients. Intensive Care Medicine 1997;23(supp 1):S184.

Timmer B, Hondebrink Y, Oude Nijhuis J, Woittiez AJJ. Restoration of colloid osmotic pressure in hypoalbuminaemic patients. Netherlands Journal of Medicine 1998;52:A42.

\section{References to studies excluded from this review \\ Boldt 1993}

Boldt J, Knothe C, Schindler E, Hammermann H, Dapper F, Hempelmann G. Volume replacement with hydroxyethyl starch solution in children. British Journal of Anaesthesia 1993;70(6):661-665.

\section{Boldt 2000b}

Boldt J, Lehmann A, Rompert R, Haisch G, Isgro F. Volume therapy with a new hydroxyethyl starch solution in cardiac surgical patients before cardiopulmonary bypass. Journal of Cardiothoracic and Vascualar Anaesthesia 2000;14(3):264-8.

\section{Brehme 1993}

Brehme S, Keysser G, Turowski A, Schmidt H. Hemorheologic effects of hydroxyethyl starch 200/0.5, dextran 40, oxypolygelatine and full electrolyte sodium over 48 hours [Hamorheologische wirkungen von hydroxyathylstarke 200/0.5, dextran 40, oxypolygelatine und vollelekttrolytlosung uber 48 studen]. Zeitschrift fur die gesamte innerve medizin und ihre grenzgebiete 1993;48(10):506-510.

\section{Bremerich 2000}

Bremerich DH, Lischke V, Asskali F, Forster H, Behne M. Pharmacodynamics and tolerability of acetyl starch as a new plasma volume expander in patients undergoing elective surgery. International Journal of Clinical Pharmacology and Therapeutics 2000;38(8):408-414.

\section{Charlet 1991}

Charlet P, Zerr C, Robert D, Merville C, Renouf P, Khayat MC. Comparative trials of fluid gelatins on hemostasis in heart surgery in adults [Essais comparatifs des gelatines fluides sur l'hemostase dans la chirurgie cardiaque de l'adulte]. Cahiers d'Anesthesiologie 1991;39 (4):233-238.

\section{Christ 1997}

Christ F, Niklas M, Kreimeier U, Lauterjung L, Peter K, Messmer K. Hyperosmotic-hyperoncotic solutions during abdominal aortic aneurysm (AAA) resection. Acta Anaesthesiologica Scandinavica 1997; 41(1):62-70. 
Emery 1992

Emery EF, Greenough A, Gamsu HR. Randomised controlled trial of colloid infusions in hypotensive preterm infants. Archives of Disease in Childhood 1992;67(10(S)):1185-1188.

\section{Gan 1999}

Gan TJ, Bennett-Guerrero E, Phillips-Bute B, Wakeling H, Moskowitz DM, Olufolabi Y, et al. Hextend, a physiologically balanced plasma expander for large volume use in major surgery: a randomized phase III clinical trial. Anesthesia and Analgesia 1999;88(5): 992-8.

Hankeln 1990

Hankeln K, Senker R, Beez M. Comparative study of the intraoperative effectiveness of $5 \%$ human albumin or $10 \%$ hydroxyethyl starch (HAES-steril) on hemodynamics and oxygen transport in 40 patients [Vergleichende Untersuchung zur intraoperativen Wirksamkeit von 5\% Humanalbumin oder 10\% Hydroxyathylstarke (HAES-steril) auf Hamodynamik und Sauerstofftransport bei 40 Patienten]. Infusionstherapie 1990;17(3):135-140.

\section{Harke 1976}

Harke H, Thoenies R, Margraf I, Momsen W. The influence of different plasma substitutes on blood clotting and platelet function during and after surgery [Der Einfluss verschiedener Plasmaersatzmittel auf Gerinnungssystem und Thrombocytenfunktion wahrend und nach operativen Eingriffen. Vorlaufige Ergebnisse einer klinischen Studie]. Anaesthesist 1976;25(8):366-373.

\section{Hiippala 1996}

Hiippala S, Teppo AM. Perioperative volume effect of HES 120/0.7 compared with dextran 70 and Ringer acetate. Annales cChirurgiae et Gynaecologiae 1996;85(4):333-339.

Huet 2000

Huet RCGG, Siemons AW, Baus D, van Rooyen-Butijn WT, Haagenaars JAM, van Oeveren W, Bepperling F. A novel hydroxyethyl starch (Voluven(TM)) for effective perioperative plasma volume substitution in cardiac surgery. Canadian Journal of Anaesthesia 2000;47 (12):1207-1215.

\section{Jovanovic 1997}

Jovanovic K, Filipovic N, Romic P, Surbatovic M. Hetastarch in replacement of circulation volume compared to haemaccel and dextran 70 in pre-hospital resuscitation of polytraumatised patients. Intensive Care Medicine. 1997; Vol. 23:S184.

\section{Korttila 1984}

Korttila K, Grohn P, Gordin A, Sundberg S, Salo H, Nissinen E, et al. Effect of hydroxyethyl starch and dextran on plasma volume and blood hemostasis and coagulation. Journal of Clinical Pharmacology 1984;24(7):273-282.

\section{Langeron 2001}

Langeron ODM, Doelberg M, Ang ET, Bonnet F, Capdevila X, Coriat $\mathrm{P}$. Voluven, a lower substituted novel hydroxyethyl starch (HES $130 / 0.4$ ) causes fewer effects on coagulation in major orthopedic surgery than HES 200/0.5. Anesthesia \& Analgesia 2001;92(4):85562.

\section{Puri 1983}

Puri VK, Howard M, Paidipaty B, Singh S. Resuscitation in hypovolemia and shock: a prospective study of hydroxyethyl starch and albumin. Critical Care Medicine 1983;11(7):518-523).

\section{Rauch 2000}

Rauch S, Sefrin P. Comparison of hydroxyethyl starch solutions derived from potato and corn starch [Vergleich von Hydroxyethylstarkelosungen aus Kartoffel- und Maisstarke]. Anasthesiologie, Intensivmedizin, Notfallmedizin, Schmerztherapie 2000;35(12):750-5.

\section{Rehm 2000}

Rehm M, Orth V, Scheingraber S, Kreimeier U, Brechtelsbauer H, Finsterer U. Acid-base changes caused by $5 \%$ albumin versus $6 \%$ hydroxyethyl starch solution in patients undergoing acute normovolemic hemodilution: a randomized prospective study. Anesthesiology 2000;93(5):1174-83.

\section{Strauss 1985}

Strauss RG, Stump DC, Henriksen RA, Saunders R. Effects of hydroxyethyl starch and fibrinogen, fibrin clot formation, and fibrinolysis. Transfusion 1985;25(3):230-234

\section{Waxman 1989}

Waxman K, Holness R, Tominaga G, Chela P, Grimes J. Hemodynamic and oxygen transport effects of pentastarch in burn resuscitation. Annals of Surgery 1989;209(3):341-345.

\section{References to studies awaiting assessment}

Hopkins 1994

Hopkins PM. 6\% hydroxyethylstarch with $4 \%$ gelatine as peri-operative intravenous volume replacement in surgical patients. National Research Register Version 1/1998.

\section{Romero 1999}

Romero J, Luna P, Fernandez B, Rojas E, Sarrano X, Alvarez H. The use of HAES-Steril $6 \%$ as a plasma expander after cardiopulmonary bypass in aortocoronary surgery [Uso de HAES esteril 6\% como expansor plasmatico despues de la circulacion extracorporea en revascularizacion coronaria]. Revista Mexicana de Anestesiologia 1999;22: $160-167$.

\section{Additional references}

\section{Altman 1996}

Altman DG, Bland JM. Detecting skewness from summary information. BMJ 1996;313:1200.

\section{Armstrong 1994}

Armstrong RF, Bullen C, Cohen SL, Singer M, Webb AR. Critical Care Algorithms. Vol. Oxford Medical Publications, Oxford University Press, 1994

\section{Berlin 1997}

Berlin JA. Does blinding of readers affect the results of meta-analyses? Lancet 1997;350:185-6.

\section{Boldt 1996}

Boldt J, Heesen M, Muller M, pabsdorf M, Hempelmann G. The effects of albumin versus hydroxyethyl starch solution on cardiorespiratory and circulatory variables in critically ill patients. Anesthesia and Analgesia 1996;83:254-61.

\section{CIGAR 2000}

The Cochrane Injuries Group Albumin Reviewers. Human albumin administration in critically ill patients (Cochrane Review). The Cochrane Library 2000, Issue 2. 


\section{Clarke 2001}

Clarke M, Oxman AD, editors. Optimal search strategy for RCTs. Cochrane Reviewers Handbook 4.1.5 [updated April 2002] appendix 5c 2002, Issue 2 .

Egger 1997

Egger M, Davey Smith G, Schneider M, Minder C. Bias in metaanalysis detected by a simple, graphical test. BMJ 1997;315:629-34.

\section{Schierhout 2000}

Schierhout G, Roberts I, Alderson P. Colloids compared to crystalloids in fluid resuscitation of critically ill patients (Cochrane Review). The Cochrane Library 2000, Issue 2.

\section{Schulz 1995}

Schulz KF, Chalmers I, Hayes RJ, Altman DG. Empirical Evidence of Bias. Dimensions of methodological quality associated with estimates of treatment effects in controlled trials. JAMA 1995;273:408-412.

\section{Traylor 1996}

Traylor RJ, Pearl RG. Crystalloid versus colloid: All colloids are not created equal. Anesthesia and Analgesia 1996;83:209-12.

\section{Vermeulen 1995}

Vermeulen LC Jr, Ratko T A, Erstad BL, Brecher ME, Matuszewski K.A. A paradigm for consensus. The University Hospital Consortium guidelines for the use of albumin, nonprotein colloid, and crystalloid solutions. Archives of Internal Medicine 1995;155(4):373-9.

\section{Yim 1995}

Yim JM, Vermeyken LC, Erstad BL, Matuszewski KA, Burnett DA, Vlasses PH. Albumin and nonprotein colloid solution use in US academic health centers. Archives of Internal Medicine 1995;155(22): 2450-5.

*Indicates the major publication for the study

\section{T A B LE S}

\section{Characteristics of included studies}

\begin{tabular}{|c|c|}
\hline Study & Allison 1999 \\
\hline Methods & $\begin{array}{l}\text { Randomised controlled trial. Randomisation was based on date of admission (on even dates patients received } \\
\text { HES) } \\
\text { Analysis not intention to treat }\end{array}$ \\
\hline Participants & $\begin{array}{l}45 \text { patients with blunt trauma who required colloid infusion. Patients were excluded if they were less than } \\
12 \text { yrs old, did not require admission to the ITU, died within } 24 \text { hours, were pregnant or in renal failure. } \\
8 \text { gelatine and } 6 \text { HES patients excluded after randomisation. }\end{array}$ \\
\hline Interventions & $\begin{array}{l}\text { 1) HES ( } 200 / 0.45 \text { Pentaspan) } n=24 \text {. } \\
\text { 2) Gelatine (gelofusine) } n=21 \\
\text { After } 24 \text { hours, colloid administration was at the discretion of the clinician. }\end{array}$ \\
\hline Outcomes & $\begin{array}{l}\text { Glasgow coma score, } \\
\text { volumes of blood and platelets infused, } \\
\text { haematological parameters. }\end{array}$ \\
\hline
\end{tabular}




\section{Characteristics of included studies (Continued)}

Notes

Data were collected until the patient left the ITU or for a maximun of 5 days. Main outcome of interest was capillary leak.

Allocation concealment $\mathrm{C}$-Inadequate

\begin{tabular}{|c|c|}
\hline Study & Asfar 2000 \\
\hline Methods & $\begin{array}{l}\text { Randomised unblinded controlled trial. Allocation using sequentially numbered sealed opaque envelopes } \\
\text { (information obtained on contact with the author). }\end{array}$ \\
\hline Participants & $\begin{array}{l}34 \text { septic, hypovolaemic, ventilated and hemodynamically controlled patients. } \\
\text { Inclusion criteria: patients aged over } 16 y \mathrm{r} \text {, systolic arterial pressure higher than } 90 \mathrm{mmHg} \text { and hypovolemia } \\
\text { defined by PAOP of } 12 \mathrm{mmHg} \text { or less. } \\
\text { Patients with an overt hemodynamic, ventilatory or acid base status instability were excluded. Sepsis was } \\
\text { identified by either positive bacterial blood cultures, bronchoalveolar lavage or clinical evidence of infection. }\end{array}$ \\
\hline Interventions & $\begin{array}{l}\text { 1) } 6 \% \text { HES }(n=16) \text {. } \\
\text { 2) } 4 \% \text { Modified fluid gelatin (MFG) }(n=18) \text {. }\end{array}$ \\
\hline$\overline{\text { Outcomes }}$ & $\begin{array}{l}\text { Haemodynamic and tonometric parameters. } \\
\text { Death. }\end{array}$ \\
\hline Notes & $\begin{array}{l}\text { Follow-up was for one hour. Two patients in the HES grp were excluded because they experienced haemo- } \\
\text { dynamic instability. The final analysis was made on remaining } 16 \text { patients. }\end{array}$ \\
\hline Allocation concealment & A - Adequate \\
\hline Study & Beards 1994 \\
\hline Methods & $\begin{array}{l}\text { Randomised controlled trial (allocation by alternation). } \\
\text { Information on allocation concealment was obtained on contact with the author. }\end{array}$ \\
\hline Participants & $\begin{array}{l}28 \text { patients with hypovolaemia, mechanically ventilated for concurrent acute respiratory failure. Patients } \\
\text { fulfilled the following inclusion criteria: age }>16 \text { yrs, body weight between } 50 \text { and } 85 \mathrm{~kg} \text {, mean arterial pressure } \\
<80 \mathrm{mmHg} \text { (or } 30 \mathrm{mmHg} \text { less than previously recorded); pulmonary artery occlusion pressure }<10 \mathrm{mmHg} \\
\text { with oliguria (i.e urine output }<15 \mathrm{ml} / \mathrm{hr} \text { ). }\end{array}$ \\
\hline Interventions & $\begin{array}{l}\text { 1) Rapid infusion of } 500 \mathrm{ml} \text { modified fluid gelatin }(\mathrm{n}=15) \text {. } \\
\text { 2) Rapid infusion of } 500 \mathrm{ml} \text { hetastarch }(\mathrm{n}=13) \text {. }\end{array}$ \\
\hline$\overline{\text { Outcomes }}$ & $\begin{array}{l}\text { Haemodynamic variables were measured for } 30 \text { minutes. } \\
\text { Oxygen variables were measured for } 30 \text { minutes. } \\
\text { Deaths in hospital reported. }\end{array}$ \\
\hline$\overline{\text { Notes }}$ & Patients were followed up to discharge from hospital. \\
\hline Allocation concealment & $\mathrm{C}$ - Inadequate \\
\hline
\end{tabular}

\begin{tabular}{ll} 
Study & Berard $\mathbf{1 9 9 5}$ \\
\hline Methods & $\begin{array}{l}\text { Randomised controlled trial. A set of } 200 \text { tickets (type 1) and another set of 200 tickets (type 2) were mixed } \\
\text { in a box. One ticket was drawn at random for each patient. Information on method of randomisation was } \\
\text { obtained on contact with the author. Blinding not mentioned. }\end{array}$ \\
\hline Participants & $\begin{array}{l}\text { 319 patients in a resuscitation service receiving medical (gastrointestinal haemorrhage) and surgical cases. } \\
\text { Patients were excluded if they had had a prior allergic reaction. }\end{array}$ \\
\hline Interventions & $\begin{array}{l}\text { 1) Gelatin }(\mathrm{n}=153) . \\
\text { 2) HES ( } \mathrm{n}=146)\end{array}$ \\
\hline The prescribers chose the quantity of colloid, guided by normal practice.
\end{tabular}




\section{Characteristics of included studies (Continued)}

\begin{tabular}{|c|c|}
\hline & Cost. \\
\hline Notes & 20 patients lost to follow up, no explanation given. Follow up to discharge. \\
\hline Allocation concealment & C - Inadequate \\
\hline Study & Beyer 1997 \\
\hline Methods & $\begin{array}{l}\text { Randomised controlled trial. } \\
\text { Allocation was by a list of random numbers read by someone not entering patients into the trial (closed list). } \\
\text { Information on method of allocation concealment was obtained by contact with the author. No blinding. }\end{array}$ \\
\hline 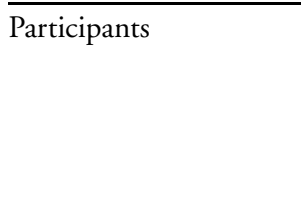 & $\begin{array}{l}48 \text { patients undergoing major elective hip surgery with an expected blood loss of }>1000 \mathrm{ml} \text {. Exclusion criteria } \\
\text { were haemoglobin concentration }<\text { or equal to } 11 \mathrm{~g} / \mathrm{dl} \text {, heart failure and coronary artery disease, myocardial } \\
\text { infarction within the past } 6 \text { months, hypertension }(>180 \mathrm{mmHg} \text { systolic), impaired renal function, pregnancy, } \\
\text { known hypersensitivity to HES or gelatin, patient taking drugs that may specifically affect blood viscosity, } \\
\text { diuresis or clotting. }\end{array}$ \\
\hline Interventions & $\begin{array}{l}\text { 1) } 3 \% \text { modified fluid gelatin }(n=22) \text {. } \\
\text { 2) } 6 \% \text { HES ( } n=19) \\
\text { Both groups also given Ringer's lactate. Fluids administered according to haemodynamic and clinical param- } \\
\text { eters. }\end{array}$ \\
\hline$\overline{\text { Outcomes }}$ & $\begin{array}{l}\text { Haemodynamic variables. } \\
\text { Packed cell volume, haemoglobin, clotting times. } \\
\text { Incidence of allergic reactions. } \\
\text { Information on death was obtained by contact with the author. }\end{array}$ \\
\hline Notes & Seven patients were lost to follow up but only 5 were accounted for. \\
\hline Allocation concealment & A- Adequate \\
\hline
\end{tabular}

\begin{tabular}{ll} 
Study & Boldt $\mathbf{1 9 8 6}$ \\
\hline Methods & Randomised controlled trial, using sealed opaque envelopes. \\
& Information on allocation concealment was obtained on contact with the authors. \\
& Blinding not mentioned. \\
& Loss to follow up not mentioned. \\
\hline Participants & 55 patients undergoing elective aorto-coronary bypass surgery. \\
& Exclusion criteria were ejection fraction $<50 \%$ and LVEDP $>15 \mathrm{mmHg}$. \\
\hline Interventions & 1) $500 \mathrm{ml} 20 \%$ human albumin solution $(\mathrm{n}=15)$ \\
& 2) $500 \mathrm{ml} 3 \%$ HES (n=13) \\
& 3) $500 \mathrm{ml} 3.5 \%$ gelatine (n= 14) \\
4) no colloid (n=13)
\end{tabular}

\begin{tabular}{ll} 
Study & Boldt 1993 A \\
\hline Methods & $\begin{array}{l}\text { Randomised controlled trial. Method of allocation concealment not described in published report. Authors } \\
\text { were contacted and confirmed the use of sequentially numbered sealed opaque envelopes. }\end{array}$ \\
\hline Participants & $\begin{array}{l}75 \text { men undergoing elective aortocoronary bypass grafting, who had a pulmonary capillary wedge pressure } \\
\text { of less than } 5 \mathrm{mmHg} \text { after induction of anaesthesia. }\end{array}$ \\
\hline Interventions & 1) Albumin $5 \% .(\mathrm{n}=15)$ \\
\hline
\end{tabular}




\section{Characteristics of included studies (Continued)}

\begin{tabular}{|c|c|}
\hline & $\begin{array}{l}\text { 2) } 6 \% \text { HES, HMW }(n=15) \\
\text { 3) } 6 \% \text { HES, LMW }(n=15) \\
\text { 4) Gelatin } 3.5 \%(n=15) \\
\text { 5) No additional volume. }\end{array}$ \\
\hline$\overline{\text { Outcomes }}$ & $\begin{array}{l}\text { Deaths not reported. Authors were contacted and confirmed that there were no deaths in the albumin nor } \\
\text { the control group. }\end{array}$ \\
\hline Notes & Follow-up 1 day. \\
\hline Allocation concealment & A-Adequate \\
\hline Study & Boldt 1995 \\
\hline$\overline{\text { Methods }}$ & $\begin{array}{l}\text { Randomised controlled trial. Randomisation was by the use of sequentially numbered sealed opaque en- } \\
\text { velopes. Information on allocation concealment was obtained on contact with the author. Blinding of out- } \\
\text { come assessors not mentioned. }\end{array}$ \\
\hline Participants & $\begin{array}{l}30 \text { consecutive trauma patients (injury severity score }>15 \text { ) and } 30 \text { consecutive septic patients who under- } \\
\text { went major surgery. Exclusions: patients suffering from renal failure requiring haemofiltration, severe liver } \\
\text { dysfunction or coagulation abnormalaties in their history were excluded as were patients who were receiving } \\
\text { aspirin or other cyclooxygenase inhibitors. }\end{array}$ \\
\hline Interventions & $\begin{array}{l}\text { 1) } 10 \% \text { HES, LMW ( } \mathrm{n}=15 \text { trauma pts and } 15 \text { sepsis patients) } \\
\text { 2) } 20 \% \text { human albumin ( } \mathrm{n}=15 \text { trauma pts and } 15 \text { sepsis pts). } \\
\text { Fluid was given to maintain CVP and PCWP between } 12 \text { and } 16 \mathrm{mmHg} \text {. }\end{array}$ \\
\hline$\overline{\text { Outcomes }}$ & $\begin{array}{l}\text { Haemodynamic parameters. } \\
\text { Deaths }\end{array}$ \\
\hline Notes & $\begin{array}{l}\text { Length of follow-up was } 5 \text { days. } \\
\text { Deaths were reported within the study period and later (time not specified). }\end{array}$ \\
\hline Allocation concealment & A-Adequate \\
\hline Study & Boldt 1996 A \\
\hline$\overline{\text { Methods }}$ & $\begin{array}{l}\text { Randomised controlled trial, allocation by sequentially numbered sealed opaque envelopes. } \\
\text { Outcome assessors blinded to treatment. }\end{array}$ \\
\hline Participants & $\begin{array}{l}30 \text { trauma patients and } 30 \text { patients suffering from sepsis secondary to major general surgery. Exclusions were } \\
\text { patients with renal impairment, liver insufficinecy, disseminated intravascular coagulation or septic shock. }\end{array}$ \\
\hline Interventions & $\begin{array}{l}\text { 1) } 10 \% \text { HES ( } \mathrm{n}=30) \\
\text { 2) } 20 \% \text { human albumin solution }(\mathrm{n}=30) \\
\text { All patients also received Ringer's lactate solution. } \\
\text { Volume therapy was given to maintain PCWP between } 12 \text { and } 18 \mathrm{~mm} \mathrm{Hg} \text {. }\end{array}$ \\
\hline Outcomes & $\begin{array}{l}\text { Haemodynamic variables. } \\
\text { Death at } 5 \text { days and discharge from intensive care. }\end{array}$ \\
\hline Notes & \\
\hline Allocation concealment & A-Adequate \\
\hline
\end{tabular}

\section{Study}

Methods

\section{Boldt 1996 B}

Randomised controlled trial. Randomisation was by the use of sequentially numbered sealed opaque envelopes. Information on allocation concealment was obtained on contact with the author.

The doctors giving the fluid were blinded to the solution but blinding of outcome assessors not mentioned. Loss to follow up not mentioned.

Participants
45 consecutive trauma patients transferred to the surgical intensive care unit. Inclusion criteria were an injury severity score of $>15$ points. 


\section{Characteristics of included studies (Continued)}

All patients were haemodynamically stable before being admitted to the study.

\begin{tabular}{ll}
\hline Interventions & 1) $10 \%$ HES $(\mathrm{n}=15)$. \\
& 2) $20 \%$ human albumin $(\mathrm{n}=15)$. \\
& 3) unspecified volume therapy regime ( $\mathrm{n}=15)$. \\
& The allocated solution was given to maintain CVP and or PAWP between 12 and $18 \mathrm{mmHg}$. \\
\hline Outcomes & Death. \\
& Haemodynamic variables. \\
& Circulating adhesion molecules. \\
\hline Notes & Deaths were reported within the study period and later (left ITU). \\
\hline Allocation concealment & A- Adequate
\end{tabular}

\begin{tabular}{ll} 
Study & Boldt $\mathbf{1 9 9 6} \mathbf{C}$ \\
\hline Methods & $\begin{array}{l}\text { Randomised controlled study. Randomisation was by the use of sequentially numbered sealed opaque en- } \\
\text { velopes. Outcome variables were collected by an investigator who was blinded to the treatment. } \\
\text { Loss to follow up not mentioned. }\end{array}$ \\
\hline Participants & $\begin{array}{l}56 \text { patients from the surgical intensive care unit. } 28 \text { patients with an injury severity score }>15 \text { and } 28 \text { patients } \\
\text { with sepsis secondary to major surgery. Patients with renal insufficiency, urine output }<20 \mathrm{ml} \text { h, severe liver } \\
\text { dysfunction or disseminated intravascular coagulation were excluded. }\end{array}$ \\
\hline Interventions & 1) $10 \%$ HES, LMW (trauma $\mathrm{n}=14$, sepsis $\mathrm{n}=14$ ) \\
& 2) $20 \%$ human albumin. (trauma $\mathrm{n}=14$, sepsis $\mathrm{n}=14$ ) \\
& Fluid was infused to maintain PCWP at 10-15mmHg. \\
\hline Outcomes & $\begin{array}{l}\text { Haemodynamic variables. } \\
\text { Death. }\end{array}$ \\
\hline Notes & Length of follow up was 5 days. \\
& Deaths were reported within the study period and later (time not specified). \\
\hline Allocation concealment & A - Adequate
\end{tabular}

\begin{tabular}{ll} 
Study & Boldt $\mathbf{1 9 9 8}$ \\
\hline Methods & $\begin{array}{l}\text { Randomised controlled trial. Sequentially numbered sealed opaque envelopes were used. Information on } \\
\text { allocation concealment was obtained on contact with the authors. } \\
\text { Blinding of outcome assessors not mentioned. } \\
\text { Loss to follow up not mentioned. }\end{array}$ \\
\hline Participants & $\begin{array}{l}150 \text { traumatised patients (injury severity score }>15) \text { and } 150 \text { postoperative patients with sepsis. Patients } \\
\text { suffering from renal failure, severe liver insufficiency, or with major coagulation abnormalaties were not } \\
\text { included. }\end{array}$ \\
\hline Interventions & $\begin{array}{l}\text { 1) } 10 \% \text { HES, LMW (n=150). } \\
\text { 2) } 20 \% \text { human albumin (n=150). Both for } 5 \text { days to maintain the pulmonary wedge pressure between } 12 \\
\text { and } 15 \text { TORR }\end{array}$ \\
\hline Outcomes & $\begin{array}{l}\text { Death. } \\
\text { Haemodynamic variables. } \\
\text { Organ function. } \\
\text { Coagulation. }\end{array}$ \\
\hline Notes & Deaths were reported within the study period and after the study period (time not specified). \\
\hline Allocation concealment & A - Adequate \\
\hline Colloid solutions for fluid resuscitation (Review) \\
Copyright $\odot \mathbf{2 0 0 7}$ The Cochrane Collaboration. Published by John Wiley \& Sons, Ltd
\end{tabular}




\section{Characteristics of included studies (Continued)}

\begin{tabular}{|c|c|}
\hline Study & Boldt 2000 \\
\hline Methods & $\begin{array}{l}\text { Randomised controlled trial. Allocation by sequentially numbered sealed opaque envelopes (information } \\
\text { obtained by contacting the author) }\end{array}$ \\
\hline Participants & 150 patients undergoing major abdominal surgery \\
\hline Interventions & $\begin{array}{l}\text { 1) } 6 \% \text { HES, LMW }(\mathrm{n}=50) \text {. } \\
\text { 2) } 6 \% \text { HES, MMW }(\mathrm{n}=50) \text {. } \\
\text { 3) } 3 \% \text { modified fluid gelatin }(\mathrm{n}=50) \\
\text { To keep MAP more than } 70 \mathrm{~mm} \mathrm{Hg} \text { and CVP between } 10 \text { and } 14 \mathrm{~mm} \mathrm{Hg} \text {. } \\
\text { Volume was given perioperatively until the morning of the first post-op day. For each hour of surgery } 500- \\
800 \mathrm{ml} \text { of crsytalloids was routinely infused. }\end{array}$ \\
\hline$\overline{\text { Outcomes }}$ & $\begin{array}{l}\text { Death. } \\
\text { Haemodynamic variables, } \\
\text { blood loss, } \\
\text { blood transfused, } \\
\text { cost. }\end{array}$ \\
\hline Notes & $\begin{array}{l}\text { Deaths were reported for the study period (when there were no deaths) and after the study period (when } \\
\text { there was } 1 \text { death in the HES } 70 \text { grp, } 2 \text { deaths in the HES } 200 \text { grp and } 1 \text { death in the gelatin grp). } \\
\text { The study period lasted until the first day post-op. }\end{array}$ \\
\hline
\end{tabular}

\begin{tabular}{|c|c|}
\hline Study & Boldt 2001 \\
\hline Methods & $\begin{array}{l}\text { Randomised controlled trial. Allocation by a "closed envelope system". } \\
\text { Volume therapy was done by doctors who did not know the aim of the study. }\end{array}$ \\
\hline Participants & $\begin{array}{l}75 \text { patients undergoing major abdominal surgery. } \\
\text { Volume was administered to keep the CVP between } 8 \text { and } 12 \mathrm{mmHg} \text {. }\end{array}$ \\
\hline Interventions & $\begin{array}{l}\text { 1) } 6 \% \text { HES }(\mathrm{n}=25) \\
\text { 2) } 6 \% \text { HES }(\mathrm{n}=25) \text {. } \\
\text { 3) } 4 \% \text { modified fluid gelatin }(\mathrm{n}=25) \\
\text { All groups also received } 500 \mathrm{ml} \text { of ringers lactate for each hour of surgery. }\end{array}$ \\
\hline Outcomes & $\begin{array}{l}\text { Death. } \\
\text { Haemodynamic variables, } \\
\text { blood loss, } \\
\text { blood transfused. }\end{array}$ \\
\hline$\overline{\text { Notes }}$ & $\begin{array}{l}\text { There were no deaths in the study period (until first postoperative day) but afterwards there was one death } \\
\text { in the colloids group and no deaths in the gelatin group. }\end{array}$ \\
\hline Allocation concealment & A-Adequate \\
\hline
\end{tabular}

\section{Study}

Methods

Participants

Interventions

\section{Brock 1995}

Randomised controlled trial with list of random numbers read by someone entering patients into the trial (open list). Data on allocation concealment was obtained on contact with the authors.

21 patients who had undergone cardiac surgery.

1) $10 \%$ HES. $200 / 0.5$ in $7.2 \%$ saline $(n=7)$

2) $5 \%$ human albumin ( $n=7)$.

3) $6 \%$ hydroxyethylstarch in $0.9 \%$ saline $(n=7)$.

Outcomes

Hemodynamic variables were collected.

Data on death was obtained on contact with the authors.

Notes 


\section{Characteristics of included studies (Continued)}

Allocation concealment $\mathrm{C}$-Inadequate

\begin{tabular}{ll} 
Study & Brutocao $\mathbf{1 9 9 6}$ \\
\hline Methods & $\begin{array}{l}\text { Randomised double-blind controlled trial with pharmacy controlled randomisation. Information on alloca- } \\
\text { tion concealment was obtained on contact with the authors. }\end{array}$ \\
\hline Participants & $\begin{array}{l}\text { Children aged 1 year or more who were undergoing surgical repair of a congenital heart disease. Exclusion } \\
\text { criteria included amrinone therapy, renal disease, coagulopathy or a known bleeding diathesis. }\end{array}$ \\
\hline Interventions & 1) $5 \%$ albumin $(\mathrm{n}=18)$. \\
& 2) $6 \%$ HES (n=20). \\
& $\begin{array}{l}\text { Volume expansion was administered as clinically indicated to maintain adequate central venous pressure, } \\
\text { perfusion and urine output. The total amount of colloid therapy was determined by care providers blinded } \\
\text { to the randomisation. }\end{array}$ \\
\hline Outcomes & $\begin{array}{l}\text { Haemodynamic variables. } \\
\text { Coagulation variables. }\end{array}$ \\
Information on death was obtained on contact with the authors. \\
\hline Notes & $\begin{array}{l}\text { Follow-up was until discharge from hospital. } \\
9 \text { children excluded post randomisation because they did not require colloid. }\end{array}$ \\
\hline Allocation concealment & A - Adequate \\
\hline
\end{tabular}

\begin{tabular}{ll} 
Study & Carli $\mathbf{2 0 0 0}$ \\
\hline Methods & $\begin{array}{l}\text { Randomised controlled trial. Each centre had a list and the patients were randomised by the regulatory Dr } \\
\text { of the Institute. }\end{array}$ \\
\hline Participants & $\begin{array}{l}164 \text { trauma patients. Patients were included if their SBP was less than } 100 \mathrm{mmHg} \text {, associated with signs of } \\
\text { hypoperfusion. }\end{array}$ \\
\hline Interventions & $\begin{array}{l}\text { 1) HES (Hesteril 6\%) ( } \mathrm{n}=85) . \\
\text { 2) Gelatin (Plasmion) } \\
(\mathrm{n}=79)\end{array}$ \\
\hline Outcomes & Glasgow coma score. \\
& $\begin{array}{l}\text { Haemodynamic variables } \\
\text { Units of blood transfused } \\
\text { Adverse reaction }\end{array}$ \\
\hline Notes & There were 13 deaths from heart failure but these patients were excluded from the final analysis. \\
\hline Allocation concealment & B - Unclear
\end{tabular}

\begin{tabular}{|c|c|}
\hline Study & Claes 1992 \\
\hline Methods & $\begin{array}{l}\text { Randomised controlled trial. No information given on method of randomisation. } \\
\text { Blinding not mentioned. } \\
\text { No loss to follow up. }\end{array}$ \\
\hline Participants & $\begin{array}{l}20 \text { patients undergoing brain tumor surgery and } 20 \text { patients undergoing transabdominal hysterectomy. } \\
\text { Exclusion criteria were preexisting coagulopathies; abnormal preoperative coagulation screening tests; intake } \\
\text { of drugs affecting haemostasis within } 2 \text { wk preoperatively as well as liver or kidney dysfunction. }\end{array}$ \\
\hline Interventions & $\begin{array}{l}\text { 1000ml of fluid for volume replacement, either as } \\
\text { 1) } 6 \% \text { HES ( } \mathrm{n}=19) \text {. } \\
\text { 2) } 5 \% \text { human albumin solution in } 0.9 \% \mathrm{NaCl}(\mathrm{n}=21) \text {. }\end{array}$ \\
\hline Outcomes & $\begin{array}{l}\text { Haemodynamic variables. } \\
\text { Coagulation variables. }\end{array}$ \\
\hline$\overline{\text { Notes }}$ & Follow up 48 hrs post-op. \\
\hline
\end{tabular}




\section{Characteristics of included studies (Continued)}

Allocation concealment $\quad B-$ Unclear

\begin{tabular}{|c|c|}
\hline Study & Diehl 1982 \\
\hline Methods & $\begin{array}{l}\text { Randomised controlled trial. Patients were allocated to groups according to their hospital identification } \\
\text { number. } \\
\text { Blinding not mentioned. } \\
\text { No loss to follow up. }\end{array}$ \\
\hline Participants & 60 Patients undergoing coronary artery bypass. \\
\hline Interventions & $\begin{array}{l}\text { 1) } 6 \% \text { HES ( } n=27) \\
\text { 2) } 5 \% \text { albumin }(n=33) \\
\text { for volume expansion during the first } 24 \text { hours postoperatively. Neither hetastarch or albumin was used } \\
\text { intraoperatively or in the pump prime. }\end{array}$ \\
\hline Outcomes & $\begin{array}{l}\text { Death. } \\
\text { Coagulation data. } \\
\text { Haemodynamic variables. }\end{array}$ \\
\hline Notes & Followup 7 days post-op. \\
\hline Allocation concealment & $\mathrm{C}$ - Inadequate \\
\hline
\end{tabular}

\begin{tabular}{ll} 
Study & Du Gres $\mathbf{1 9 8 9}$ \\
\hline Methods & $\begin{array}{l}\text { Randomised controlled trial. No information given on method of randomisation. } \\
\text { Blinding not mentioned. } \\
\text { No loss to follow up. }\end{array}$ \\
\hline Participants & $\begin{array}{l}30 \text { patients post cardiac surgery. Patients were included if they were haemodynamically stable, were without } \\
\text { serious 'rhythm' problems, had a mean arterial pressure less than } 90 \mathrm{mmHg} \text {, a mean pulmonary artery pressure } \\
\text { less than } 20 \mathrm{mmHg} \text { and a central venous pressure less than } 10 \mathrm{mmHg} \text {. Patients excluded if they needed blood } \\
\text { transfusion, had a hematocrit less than } 28 \% \text { or haemoglobin less than } 9 \mathrm{~g} / 100 \mathrm{ml} .\end{array}$ \\
\hline Interventions & $\begin{array}{l}\text { 1) } 4 \% \text { human albumin }(\mathrm{n}=15) . \\
\text { 2) Haemaccel (n=15). }\end{array}$ \\
\hline Outcomes & Haemodynamic parameters. \\
\hline Notes & Follow up 4 hours. \\
\hline Allocation concealment & B - Unclear \\
\hline
\end{tabular}

\section{Study}

Methods

Participants

Interventions

Notes

Allocation concealment

\section{Dytkowska 1998}

Randomised controlled trial. No information given on method of allocation concealment

40 patients post cardiac surgery. Patients were excluded if they had co-existing cardiogenic shock, renal failure with creatine level over $3.0 \mathrm{mg}$ or severe clotting disorders.

1) $200 / 0$ HAES $6 \%(n=20)$.

2) Gelafundin $(n=20)$

Colloids were administered to patients with diagnosed symptoms of hypovolaemia, during the first 24 hours post-op. Infusion rate was adjusted to patients needs but it did not exceed $1000 \mathrm{ml} / \mathrm{h}$

Colloid solutions for fluid resuscitation (Review)

Copyright $\odot 2007$ The Cochrane Collaboration. Published by John Wiley \& Sons, Ltd

Biochemical parameters.

Adverse reactions.

Follow up 2 hours.

B - Unclear 


\section{Characteristics of included studies (Continued)}

\begin{tabular}{ll} 
Study & Falk $\mathbf{1 9 8 8}$ \\
\hline Methods & Randomised controlled trial. No information given on method of randomisation. \\
& Blinding not mentioned. \\
& No loss to follow up. \\
\hline Participants & $\begin{array}{l}12 \text { patients with septic shock. Patients were excluded from the study if the pretreatment PAWP was greater } \\
\text { than } 10 \mathrm{mmHg} .\end{array}$ \\
\hline Interventions & 1) $250 \mathrm{ml}$ of $5 \%$ albumin $(\mathrm{n}=6)$. \\
& 2) $250 \mathrm{ml}$ of $6 \%$ HES ( $\mathrm{n}=6)$. \\
& $\begin{array}{l}\text { every } 15 \text { minutes until the PAWP was increased to } 15 \mathrm{mmHg} \text {. The test infusion was then continued at } 100 \\
\text { mL/hour to maintain PAWP at } 15 \mathrm{~mm} \mathrm{Hg} \text { for the next } 24 \text { hours. }\end{array}$ \\
\hline Outcomes & Haemodynamic variables. \\
& Clotting variables. \\
\hline Notes & Follow up 24 hours. \\
\hline Allocation concealment & B - Unclear \\
\hline
\end{tabular}

\section{Study}

Methods

Participants

\begin{tabular}{ll}
\hline Interventions & 1) $500 \mathrm{ml}$ of a $4 \%$ solution of human albumin in Ringer's lactate $(\mathrm{n}=8)$ \\
& $\begin{array}{l}\text { 2) } 500 \mathrm{ml} \text { of hydroxyethylstarch }(\mathrm{n}=8) \\
\text { until starting cardiopulmonary bypass. }\end{array}$ \\
\hline Outcomes & Haemodynamic variables. \\
\hline Notes & Follow up 30 minutes. \\
\hline Allocation concealment & B - Unclear \\
\hline
\end{tabular}

\section{Fulachier 1994}

Randomised controlled trial. No information given on method of randomisation.

Blinding not mentioned.

No loss to follow up.

16 patients undergoing cardiac surgery ( 8 were undergoing valve replacement and 8 coronary bypass) Patients were excluded if they were over 80 , under 18 yrs of age, had been included in other studies, had received colloids in the month preceding surgery, had coagulation abnormalaties or who were undergoing inotropic treatment.

\begin{tabular}{ll} 
Study & Gahr $\mathbf{1 9 8 1}$ \\
\hline Methods & Randomised controlled trial. No information given on method of randomisation. \\
& No loss to follow up \\
\hline Participants & 20 patients with hypovolaemia following abdominal surgery for malignoma. \\
\hline Interventions & $\begin{array}{l}\text { 1) } 500 \mathrm{ml} \text { HES } 450 / 0.7(\mathrm{n}=10) . \\
\text { 2) } 500 \mathrm{ml} \text { human albumin } 5 \%(\mathrm{n}=10) \\
\text { during the first } 24 \text { hrs after the operation }\end{array}$ \\
\hline Outcomes & Haemodynamic parameters \\
& Coagulation data. \\
\hline Notes & Follow up 6 hrs. \\
\hline Allocation concealment & B - Unclear
\end{tabular}

\section{Study}

Methods

Participants

\section{Gallagher 1985}

Randomised controlled trial. Author contacted - allocation concealment by computerised system - patient details were entered before treatment assignment was revealed.

10 patients after coronary artery bypass graft surgery. 


\section{Characteristics of included studies (Continued)}

Exclusions: patients with significant left main coronary artery stenosis, poor left ventricular function or poor pulmonary function.

\begin{tabular}{ll}
\hline Interventions & 1) $5 \%$ albumin $(\mathrm{n}=5)$. \\
& 2) $6 \% \operatorname{HES}(\mathrm{n}=5)$. \\
\hline Outcomes & Data on deaths from author. \\
& Haemodynamic data. \\
\hline Notes & Follow up 1 day. \\
\hline Allocation concealment & A- Adequate \\
\hline
\end{tabular}

\begin{tabular}{|c|c|}
\hline Study & Gold 1990 \\
\hline Methods & $\begin{array}{l}\text { Randomised controlled trial. Randomisation was done by alternation. Colloid solution was blinded by } \\
\text { covering with foil. Information on allocation concealment was obtained by contact with the author. } \\
\text { No loss to follow up. }\end{array}$ \\
\hline Participants & 40 Surgical patients undergoing abdominal aortic aneurysm surgery. \\
\hline Interventions & $\begin{array}{l}\text { 1) } 1 \mathrm{~g} / \mathrm{kg} \text { of albumin } 5 \% \text { solution }(\mathrm{n}=20) \text {. } \\
\text { 2) } 1 \mathrm{~g} / \mathrm{kg} \text { or hetastarch } 6 \% \text { solution }(\mathrm{n}=20) \text {. }\end{array}$ \\
\hline Outcomes & $\begin{array}{l}\text { Haemodynamic and coagulation variables were measured. Data on death was obtained on contact with the } \\
\text { author. }\end{array}$ \\
\hline$\overline{\text { Notes }}$ & Length of follow up not specified. \\
\hline Allocation concealment & $\mathrm{C}$ - Inadequate \\
\hline Study & Haisch 2001a \\
\hline Methods & $\begin{array}{l}\text { Randomised controlled trial. No information given on method of allocation concealment. } \\
\text { Patient management by doctors who were blided to the grouping. }\end{array}$ \\
\hline Participants & $\begin{array}{l}42 \text { patients undergoing cardiac surgery. Patients were excluded if they had: an MI within previous } 3 \text { months, } \\
\text { renal insufficiency, liver insufficiency, non controlled diabetes mellitus, preoperative coagulation abnormal- } \\
\text { ities or patients treated with heparin or cyclooxygenase inhibitors within last } 7 \text { days. }\end{array}$ \\
\hline Interventions & $\begin{array}{l}\text { 1) Gelatin }(n=21) \text {. } \\
\text { 2) HES }(n=21) \text {. }\end{array}$ \\
\hline Outcomes & $\begin{array}{l}\text { Deaths. } \\
\text { Use of blood products. }\end{array}$ \\
\hline$\overline{\text { Notes }}$ & Follow up until first postoperative day. \\
\hline Allocation co & B-Unclear \\
\hline
\end{tabular}

\section{Study}

Methods

Participants

Interventions

\section{Haisch 2001b}

Randomised controlled trial using computer generated random numbers. No information given on allocation concealment.

42 patients undergoing major abdominal surgery for malignancies.

Patients were excluded if they had cardiac insufficiency, renal insufficiency, altered liver function, pre-operative anemia, pre-operative coagulation abnormalities or if they had had cycloxygenase inhibitors.

1) HES ( $n=21)$.

2) Gelatin $(n=21)$

until the morning of the first post-operative day.

Outcomes Death.

Use of allogenic blood products. 


\section{Characteristics of included studies (Continued)}

\begin{tabular}{ll}
\hline Coagulation variables. \\
\hline Notes & Follow up until first postoperative day. \\
\hline Allocation concealment & B - Unclear \\
\hline Study & Hausdorfer $\mathbf{1 9 8 6}$ \\
\hline Methods & Randomised controlled trial. No information given on method of randomisation. \\
\hline Participants & $\begin{array}{l}\text { 30 children undergoing major surgery. During about } 3 \text { hours of surgery, the patients lost up to 15\% of blood } \\
\text { volume. }\end{array}$ \\
\hline Interventions & $\begin{array}{l}\text { 1) Human albumin } 5 \% \text { ( }=15) . \\
\text { 2) HES 6\% (n=15) with 14ml/kg body weight each, respectively. }\end{array}$ \\
\hline Outcomes & Haemodynamic variables. \\
\hline Notes & Follow up 24 hours post-op. \\
\hline Allocation concealment & B - Unclear
\end{tabular}

\begin{tabular}{ll} 
Study & Hedstrand $\mathbf{1 9 8 7}$ \\
\hline Methods & $\begin{array}{l}\text { Randomised controlled trial. no information given on method of randomisation. } \\
\text { Post-op care staff were blinded. } \\
\text { No loss to follow up. }\end{array}$ \\
\hline Participants & $\begin{array}{l}275 \text { patients underdoing major surgery. Patients were excluded if they if they were known to have decreased } \\
\text { serum albumin levels or expected to sustain plasma loss, or had pronounced cardiovascular disease. }\end{array}$ \\
\hline Interventions & 1) PPF (n=142). \\
& 2) Dextran (n=133. \\
\hline Outcomes & Volume transfused. \\
& Complication rates. \\
& Serum albumin \\
Deaths
\end{tabular}

\section{Study}

Methods

\begin{tabular}{ll} 
& $\begin{array}{l}\text { Blinding not mentioned } \\
\text { 3 patients lost to follow }\end{array}$ \\
\hline Participants & $\begin{array}{l}60 \text { patients undergoing } \\
\text { drugs or had a diagnosed }\end{array}$ \\
\hline Interventions & 1) $3 \%$ dextrose $(n=15)$. \\
& 2) $4 \%$ HES $(n=15)$. \\
3) $6 \% \operatorname{HES~}(n=15)$. \\
4) $5 \%$ albumin $(n=15)$.
\end{tabular}

Outcomes Haemodynamic variables.

Clotting variables.

Blood loss.

Notes

Allocation concealment $\mathrm{B}$ - Unclear 


\section{Characteristics of included studies (Continued)}

\begin{tabular}{|c|c|}
\hline Study & Huskisson 1993 \\
\hline Methods & Randomised controlled trial. No information given on method of randomisation. \\
\hline Participants & 27 children returning to the intensive care unit following hypothermic open heart surgery. \\
\hline Interventions & $\begin{array}{l}\text { 1) Albumin. } \\
\text { 2) Gelatin. } \\
\text { 3) Hetastarch. }\end{array}$ \\
\hline Outcomes & Haemodynamic variables. \\
\hline \multicolumn{2}{|l|}{$\overline{\text { Notes }}$} \\
\hline Allocation concealment & B - Unclear \\
\hline Study & Huttner 2000 \\
\hline Methods & $\begin{array}{l}\text { Randomised controlled trial. Allocation concealment using 'blind envelopes'. Anaesthetists responsible for } \\
\text { patients management were blinded to the grouping. }\end{array}$ \\
\hline Participants & $\begin{array}{l}60 \text { patients undergoing major abdominal surgery. Patients were excluded if they had any of the following: } \\
\text { cardiac insufficiency, renal insufficiency, liver dysfunction, pre-operative anaemia or coagulation abnormali- } \\
\text { ties, or were on cyclooxygenase inhibitors or non steroidal therapy. }\end{array}$ \\
\hline Interventions & $\begin{array}{l}\text { 1) } 4 \% \text { Gelatin }(n=20) \\
\text { 2) } 6 \% \text { LMW HES }(n=20) \\
\text { 3) } 6 \% \text { MMW HES }(n=20)\end{array}$ \\
\hline Outcomes & $\begin{array}{l}\text { Haemodynamic variables. } \\
\text { Clotting. variables. } \\
\text { Death }\end{array}$ \\
\hline Notes & Follow up until first postoperative day. \\
\hline Allocation concealment & A - Adequate \\
\hline
\end{tabular}

\section{Study}

Methods

\section{Karanko 1987}

Randomised controlled trial. Patients were randomised in blocks of four. Paper was put into a hat and taken out by an independant person. Information on method of randomisation was obtained on contact with the author.

Blinding not mentioned.

No loss to follow up.

Participants $\quad 48$ patients who had undergone coronary bypass surgery 20 hrs earlier.

Interventions 1 1) $4 \% \operatorname{PPF}(n=15)$.

2) $6 \%$ dextran-70 ( $n=10)$.

3) $5.5 \%$ Oxypolygelatin $(n=12)$,

4) Control group $(n=11)$. This group were not selected randomly.

Outcomes Hemodynamic variables.

Data on death was obtained on contact with the author.

Notes

Follow up 28 hrs. No deaths within the study period.

Allocation concealment $\mathrm{C}$-Inadequate

Study

Kirklin 1984

Methods

Randomised controlled trial. No information given on method of randomisation.

Blinding not mentioned.

No loss to follow up. 


\section{Characteristics of included studies (Continued)}

\begin{tabular}{ll} 
Participants & 30 patients undergoing coronary artery operations. Patients were excluded if they had undergone previous \\
& cardiac operations, if they had severe coagulopathies, anemia or chronic renal failure. \\
\hline Interventions & 1) $6 \%$ HES $(\mathrm{n}=15)$. \\
& 2) $5 \%$ albumin $(\mathrm{n}=15)$. \\
& Both fluids infused over 24 hours to maintain left artial pressure between 6 and $12 \mathrm{mmHg}$ and cardiac index \\
& greater than $2.0 \mathrm{~L} / \mathrm{min} / \mathrm{m} 2$ \\
\hline Outcomes & Haemodynamic and coagulation variables and data on death and adverse reactions were collected. \\
\hline Notes & Follow up until discharge from Intensive care. \\
& 34 patients were originally included in the trial but data from 4 of them was not included in the final analysis. \\
\hline Allocation concealment & B - Unclear
\end{tabular}

\begin{tabular}{ll} 
Study & Lisander $\mathbf{1 9 9 6}$ \\
\hline Methods & $\begin{array}{l}\text { Randomised controlled trial. Randomisation using sequentially numbered sealed opaque envelopes. Infor- } \\
\text { mation on allocation concealment was obtained on contact with the author. } \\
\text { No loss to follow up. } \\
\text { Blinding not mentioned. }\end{array}$ \\
\hline Participants & 40 patients undergoing revision hip arthroplasty. \\
\hline Interventions & 1) albumin $40 \mathrm{~g} / \mathrm{L}(\mathrm{n}=20)$. \\
& 2) dextran $7060 \mathrm{~g} / \mathrm{L}(\mathrm{n}=20)$. \\
& Patients all received enoxaparin $40 \mathrm{mg}$ daily. \\
\hline Outcomes & External blood loss. \\
& Red cell balance. \\
& Packed cell volume. \\
\hline Notes & Follow up until discharge from hospital. Data on death was obtained on contact with the author. \\
\hline Allocation concealment & A - Adequate \\
\hline
\end{tabular}

\begin{tabular}{ll} 
Study & London $\mathbf{1 9 8 9}$ \\
\hline Methods & Randomised controlled trial. No information given on method of randomisation. \\
& Blinding not mentioned. \\
& No loss to follow up. \\
\hline Participants & 93 male cardiac surgical patients. Patients were excluded from the study if they had a significant coagulopathy \\
& or were anaemic (haematocrit value $<30 \%)$. \\
\hline Interventions & 1) $10 \%$. pentastarch in $0.9 \%$ saline $(\mathrm{n}=50)$. \\
& 2) $5 \%$ human albumin in $0.9 \%$ saline $(\mathrm{n}=44)$ \\
& to provide volume expansion during the first 24 hours after cardiac operations. \\
\hline Outcomes & Haemodynamic variables. \\
& Coagulation variables. \\
& Death. \\
& Length of stay. \\
\hline Notes & One patient was treated twice with an 8 -month interval. Follow up until discharge from hospital. \\
\hline Allocation concealment & B - Unclear \\
\hline
\end{tabular}

\section{Study}

Methods

\section{Mastroianni 1994}

Randomised controlled trial. No information given on method of randomisation. Blinding not mentioned.

Participants 34 patients undergoing open heart surgery were enrolled. 


\section{Characteristics of included studies (Continued)}

\begin{tabular}{|c|c|}
\hline Interventions & $\begin{array}{l}\text { 1) } 10 \% \text { pentastarch. }(n=12) \text {. } \\
\text { 2) } 5 \% \text { albumin }(n=17) \text {. }\end{array}$ \\
\hline$\overline{\text { Outcomes }}$ & $\begin{array}{l}\text { Haemodynamics variables. } \\
\text { Clotting variables. } \\
\text { Pulmonary oedema. } \\
\text { Death. }\end{array}$ \\
\hline Notes & $\begin{array}{l}\text { Follow up } 7 \text { days. } \\
\text { Four patients in the pentastarch group, and one patient in the albumin group were excluded after randomi- } \\
\text { sation. }\end{array}$ \\
\hline Allocation concealment & B - Unclear \\
\hline Study & Moggio 1983 \\
\hline$\overline{\text { Methods }}$ & $\begin{array}{l}\text { Patients were randomised according to the last digit of their hospital identification numbers. } \\
\text { No loss to follow up. } \\
\text { Blinding not mentioned. }\end{array}$ \\
\hline Participants & $\begin{array}{l}47 \text { postoperative open heart surgery patients. Operations performed included coronary revascularisation, } \\
\text { valve operations, and combined coronary and valve procedures. Patients with pre existing hepatic or renal } \\
\text { disease were not eligible for the study. }\end{array}$ \\
\hline Interventions & $\begin{array}{l}\text { 1) } 5 \% \text { albumin in } 0.9 \% \mathrm{NaCl}(\mathrm{n}=23) \text {. } \\
\text { 2) } 6 \% \mathrm{HES} \text { in } 0.9 \% \mathrm{NaCl}(\mathrm{n}=24) \text {. }\end{array}$ \\
\hline Outcomes & $\begin{array}{l}\text { Haemodynamic variables. } \\
\text { Clotting variables. }\end{array}$ \\
\hline Notes & Follow up not specified. \\
\hline Allocation concealment & $\mathrm{C}$ - Inadequate \\
\hline Study & Munoz 1980 \\
\hline Methods & $\begin{array}{l}\text { Randomised controlled trial. No information given on method of randomisation. } \\
\text { Blinding not mentioned. } \\
\text { No mention of loss to follow up. }\end{array}$ \\
\hline Participants & 14 patients with shock due to haemorrhage or sepsis. \\
\hline Interventions & $\begin{array}{l}\text { Patients received either } \\
\text { 1) HES (hespan) } \\
\text { 2) } 5 \% \text { albumin } \\
\text { Number in each group not reported. }\end{array}$ \\
\hline Outcomes & Haemodynamic variables. \\
\hline Notes & Follow up 4 hrs post infusion. \\
\hline Allocation concealment & B - Unclear \\
\hline
\end{tabular}

\begin{tabular}{ll} 
Study & Munsch $\mathbf{1 9 8 8}$ \\
\hline Methods & Randomised controlled trial. No information given on method of randomisation. \\
& Blinding not mentioned. \\
& No loss to follow up. \\
\hline Participants & 40 consecutive patients undergoing elective coronary artery bypass graft surgery. \\
\hline Interventions & 1) HES 6\% $(\mathrm{n}=20)$ or \\
& 2) PPF (n=20) \\
& as their postoperative volume expander. \\
\hline
\end{tabular}




\section{Characteristics of included studies (Continued)}

\begin{tabular}{ll} 
Outcomes & Haemodynamic variables. \\
& Clotting variables. \\
& Death. \\
& Adverse reactions. \\
\hline Notes & Follow up 7 days post -op. \\
\hline Allocation concealment & B - Unclear \\
\hline
\end{tabular}

\begin{tabular}{|c|c|}
\hline Study & Prien 1990 \\
\hline Methods & $\begin{array}{l}\text { Randomised controlled trial. Method of allocation concealment unknown. } \\
\text { Blinding not mentioned. } \\
\text { Loss to follow up not mentioned. }\end{array}$ \\
\hline Participants & $\begin{array}{l}18 \text { patients undergoing modified Whipple's operation (hemipancreato-duodenectomy). Patients were eligible } \\
\text { for the study if there was an absence of major organ dysfunction and serum protein, sodium, glucose, blood } \\
\text { urea nitrogen, haematocrit, aPTT and PT times, and platelet times were within normal limits. Specific } \\
\text { exclusion criteria included compensated myocardial insufficiency, chronic hypertension, chronic obstructive } \\
\text { airways disease and insulin-dependent diabetes mellitus. }\end{array}$ \\
\hline Interventions & $\begin{array}{l}\text { 1) } 10 \% \text { HES ( } n=6) \text {. } \\
\text { 2) } 20 \% \text { human albumin }(n=6) \text {. } \\
\text { 3) Ringer's lactate ( } n=6) \\
\text { All given as a volume replacement solution, which was given to maintain central venous pressure at the pre- } \\
\text { operative level. }\end{array}$ \\
\hline Outcomes & $\begin{array}{l}\text { Haemodynamic variables. } \\
\text { Clotting variables. } \\
\text { Data on death was obtained on contact with the author. }\end{array}$ \\
\hline$\overline{\text { Notes }}$ & $\begin{array}{l}\text { Follow up not specified. } \\
\text { Study was intra-operative. }\end{array}$ \\
\hline Allocation concealment & B - Unclear \\
\hline
\end{tabular}

\begin{tabular}{ll} 
Study & Rackow $\mathbf{1 9 8 3}$ \\
\hline Methods & $\begin{array}{l}\text { Randomised controlled trial, method of allocation concealment not mentioned. } \\
\text { Blinding not mentioned. }\end{array}$ \\
\hline Participants & $\begin{array}{l}18 \text { patients with hypovolemic and septic shock. Patients were excluded if they were less than } 18 \text { yrs of age, } \\
\text { considered to be in a terminal state, or had a significant coagulopathy. }\end{array}$ \\
\hline Interventions & $\begin{array}{l}\text { 1) albumin ( } \mathrm{n}=9) . \\
\text { 2) HES (n=9). } \\
\text { Patients received } 250 \mathrm{ml} \text { of the treatment fluid every } 15 \text { min as a fluid challenge. The fluid challenge ended } \\
\text { when the WP equalled } 15 \\
\text { mmHg. Thereafter the treatment fluid was given in sufficient quantities to maintain the WP at } 15 \mathrm{mmHg} \\
\text { for the next } 24 \mathrm{~h} \text {, at which point the study was completed. }\end{array}$ \\
\hline Outcomes & $\begin{array}{l}\text { Death. } \\
\text { Haemodynamic variables. } \\
\text { Respiratory variables. }\end{array}$ \\
\hline Notes & $\begin{array}{l}\text { Deaths given for study period and for length of hospital stay. Survival until discharge was used for the } \\
\text { mortality data for this review. }\end{array}$ \\
\hline Allocation concealment & B - Unclear \\
\hline
\end{tabular}

\section{Study}

\section{Rackow 1989}

Methods Randomised controlled trial. Method of allocation concealment was not recorded.




\section{Characteristics of included studies (Continued)}

\begin{tabular}{ll} 
& $\begin{array}{l}\text { No loss to follow up. } \\
\text { Blinding not mentioned. }\end{array}$ \\
\hline Participants & 20 patients with severe sepsis and systemic hypoperfusion. Patients were excluded from the study if they were \\
& $<21$ yrs of age, pregnant, considered to be terminal, or they manifested spontaneous bleeding. \\
\hline Interventions & 1) $5 \%$ albumin ( $\mathrm{n}=10)$ \\
& 2) $10 \%$ hydroxyethyl starch (pentastarch) $(\mathrm{n}=10)$ \\
& Each group received $250 \mathrm{ml}$ of the treatment fluid every 15 mins until either the WP was $>$ or equal to $15 \mathrm{~mm}$ \\
& Hg or a maximum volume of $2000 \mathrm{ml}$ of study colloid was infused. \\
\hline Outcomes & Haemodynamic variables \\
& Clotting variables \\
& Deaths \\
& Allergic reactions. \\
\hline Notes & Length of follow up unspecified. \\
\hline Allocation concealment & B - Unclear \\
\hline
\end{tabular}

\begin{tabular}{ll} 
Study & Rosencher $\mathbf{1 9 9 2}$ \\
\hline Methods & $\begin{array}{l}\text { Randomised controlled trial. Randomisation was done using sequentially numbered, sealed, opaque en- } \\
\text { velopes. Information on allocation concealment was obtained on contact with the author. } \\
\text { No mention of blinding. } \\
\text { Loss to follow up not mentioned. }\end{array}$ \\
\hline Participants & 16 patients undergoing total hip replacement. \\
\hline Interventions & 1) $4 \%$ albumin \\
& 2) elohes (LMW hydroxyethyl starch). \\
& Numbers in each group not reported. \\
\hline Outcomes & Bleeding. \\
Clotting variables. \\
\hline Notes & Data on death was obtained on contact with the author. \\
\hline Allocation concealment & Follow up for 5 days post op. \\
\hline
\end{tabular}

\begin{tabular}{ll} 
Study & Schortgen $\mathbf{2 0 0 1}$ \\
\hline Methods & $\begin{array}{l}\text { Randomised controlled trial. Allocation was by sealed opaque envelopes serially numbered and used in } \\
\text { sequence. }\end{array}$ \\
\hline Participants & $\begin{array}{l}129 \text { patients with severe sepsis or septic shock over } 18 \text { years of age. Patients were excluded if they were } \\
\text { pregnant, had a history of allergy to HES or gelatin, had severe acute or chronic renal dysfunction or previous } \\
\text { administration of HES or mannitol. }\end{array}$ \\
\hline Interventions & 1) $6 \%$ hydroxyethylstarch $(\mathrm{n}=65)$. \\
& 2) $3 \%$ fluid-modified gelatin $(\mathrm{n}=64)$. \\
\hline Outcomes & Death. \\
& Length of stay in ITU. \\
& Acute renal failure. \\
\hline Notes & Follow up while in ITU. \\
& Data on death. was obtained on contact with the author. \\
\hline Allocation concealment & A - Adequate
\end{tabular}

\begin{tabular}{|c|c|}
\hline Study & Shatney 1983 \\
\hline Methods & Controlled clinical trial. Patients were assigned to groups in an alternating fashion. \\
\hline
\end{tabular}




\section{Characteristics of included studies (Continued)}

\begin{tabular}{ll} 
& $\begin{array}{l}\text { No loss to follow up. } \\
\text { No mention of blinding. }\end{array}$ \\
\hline Participants & $\begin{array}{l}32 \text { patients with multisystem trauma and/or haemorrhagic shock. Patients with cardiac arrest on hospital } \\
\text { admission or during the first half hour after admission were excluded from the study. }\end{array}$ \\
\hline Interventions & 1) Plasma protein fraction (PPF) $5 \%$ solution $(\mathrm{n}=16)$, \\
& 2) Hetastarch $6 \%(\mathrm{n}=16)$. \\
& $\begin{array}{l}\text { Study patients continued to receive the assigned colloid solution for the first } 8 \text { days whenever colloid was } \\
\text { thought necessary. }\end{array}$ \\
\hline Outcomes & Hepatic, pulmonary and renal function. \\
& Clotting variables \\
& Volume of fluids infused. \\
& Deaths \\
\hline Notes & Follow up 8 days. \\
\hline Allocation concealment & C - Inadequate \\
\hline
\end{tabular}

\begin{tabular}{ll} 
Study & Stockwell $\mathbf{1 9 9 2}$ \\
\hline Methods & Randomised controlled trial. No information given on method of randomisation. \\
& $\begin{array}{l}\text { No loss to follow up. } \\
\text { Blinding not mentioned. }\end{array}$ \\
\hline Participants & $\begin{array}{l}475 \text { patients admitted to the intensive care unit. Patients were excluded from the study if they were under } \\
18 \text { yrs or if admitted for cardiac monitoring or cardiac thrombolytic therapy. }\end{array}$ \\
\hline Interventions & 1) $4.5 \%$ albumin $(\mathrm{n}=226)$. \\
& 2) A synthetic colloid polygeline (Haemaccel) $(\mathrm{n}=249)$ \\
& for intravenous volume replacement. \\
\hline Outcomes & Death. \\
& Length of stay in ITU. \\
& Incidence of renal failure. \\
& Pulmonary oedema. \\
\hline Notes & Follow up until discharge from ITU. \\
\hline Allocation concealment & B - Unclear \\
\hline
\end{tabular}

\section{Study}

Methods

\section{Stoddart 1996}

Randomised blinded trial. Sequentially numbered sealed opaque envelopes were used. Information on allocation concealment was obtained on contact with the author.

Anaesthetist unaware of intervention.

No loss to follow up.

Participants

30 neonates undergoing major surgery. They were excluded if the body weight was less than $2 \mathrm{~kg}$ or more than $5 \mathrm{~kg}$, the preoperative haemoglobin was less than $14 \mathrm{~g} / \mathrm{d} 1$, they had previously received blood or colloid, or they had suspected major cardiac, renal, metabolic or chromosomal abnormalities. Neonates were withdrawn from the study if either blood or more than $40 \mathrm{ml} / \mathrm{kg}$ of colloid was required either during or within the first $24 \mathrm{hr}$ after surgery.

\begin{tabular}{ll}
\hline Interventions & 1) Human albumin solution $4.5 \%(\mathrm{n}=15)$. \\
& 2) Haemaccel $(\mathrm{n}=15)$. \\
\hline Outcomes & Haemodynamic variables. \\
& Plasma albumin. \\
& Haemoglobin. \\
\hline Notes & Follow up 24 hrs post op. \\
\hline Colloid solutions for fluid resuscitation (Review) \\
Copyright $\odot \mathbf{2 0 0 7}$ The Cochrane Collaboration. Published by John Wiley \& Sons, Ltd
\end{tabular}




\section{Characteristics of included studies (Continued)}

Data on deaths not collected.

Allocation concealment A-Adequate

Study

Methods

Participants

Interventions

\section{Tollofsrud 1995}

Randomised controlled trial. Allocation concealment was by the use of sequentially numbered sealed opaque envelopes. Information on allocation concealment was obtained on contact with the authors.

No loss to follow up.

Blinding not mentioned.

40 Patients undergoing elective coronary artery bypass surgery. Patients with left ventricular ejection fraction less than 40\%, valvular heart disease, ventricular aneurysm, arrhythmia, diabetes mellitus, renal failure or lung disease were excluded.

1) Polygeline (Haemaccel) $(n=10)$

2) Dextran $70(n=10)$

3) Albumin $40(n=10)$

4) Ringers Lactate $(n=10)$.

Outcomes Death.

Haemodynamic variables.

Respiratory data.

Cost of fluid regimens.

Notes

Length of follow up 48 hours during and after surgery.

Allocation concealment A-Adequate

\begin{tabular}{ll} 
Study & Vogt $\mathbf{1 9 9 4}$ \\
\hline Methods & Randomised controlled trial. No information given on method of randomisation. \\
\hline Participants & $\begin{array}{l}40 \text { patients undergoing major surgery. Exclusion criteria included anaemia, renal, liver and coagulation } \\
\text { disorders. }\end{array}$ \\
\hline Interventions & 1) $5 \%$ human albumin $(\mathrm{n}=20)$. \\
& 2) $6 \%$ hydroxyethyl starch $(\mathrm{n}=20)$. \\
\hline Outcomes & Haemodynamic variables. \\
& $\begin{array}{l}\text { Coagulation. } \\
\text { Haematological parameters. } \\
\text { Blood loss and blood intake. }\end{array}$ \\
\hline Notes & \\
\hline Allocation concealment & B - Unclear \\
\hline
\end{tabular}

Study $\quad$ Vogt 1996

Methods The patients were divided into two groups using random numbers.

Blinding not mentioned.

No loss to follow up.

Participants $\quad 41$ patients undergoing total hip arthroplasty during the perioperative period. Exclusion criteria were weight $<60 \mathrm{~kg}$, age $<18 \mathrm{yrs}$, ASA grade>III, haematocrit $<34 \%$ or $>44 \%$, history of coagulopathies or a Quick's prothrombin test of $<75 \%$, partial thromboplastin time (PTT) $>45 \mathrm{~s}$, platelet count $<100,000 / \mathrm{mm} 3$, impaired liver function and renal failure.

\begin{tabular}{ll}
\hline Interventions & 1) $6 \%$ HES ( $=20)$. \\
& 2) $5 \%$ human albumin $(n=21)$.
\end{tabular}

Outcomes Haemodynamic.

Colloid solutions for fluid resuscitation (Review)

Copyright $\odot 2007$ The Cochrane Collaboration. Published by John Wiley \& Sons, Ltd 


\section{Characteristics of included studies (Continued)}

\begin{tabular}{ll} 
& Clotting variables. \\
\hline Notes & Length of follow up was 6 hrs post-op. \\
\hline Allocation concealment & B - Unclear \\
\hline Study & Vogt $\mathbf{1 9 9 9}$ \\
\hline Methods & Randomised controlled trial. No information given on method of randomisation. \\
\hline Participants & $\begin{array}{l}50 \text { patients undergoing radical prostatectomy or cystectomy with bladder replacement. } \\
\text { Exclusion criteria were: weight less than } 60 \mathrm{~kg}, \\
\text { age less than } 21 \text { yrs, ASA } 1 \text { or 2, } \\
\text { haemoglobin less than 12g/dl, } \\
\text { history of clotting disorders, } \\
\text { liver function disorders, } \\
\text { advanced renal insufficiency or hypoproteinaemnia. }\end{array}$ \\
\hline Interventions & $\begin{array}{l}\text { 1) } 5 \% \text { human albumin. } \\
\text { 2) } 6 \% \text { HES 200/0.5. }\end{array}$ \\
\hline Outcomes & $\begin{array}{l}\text { Haemodynamic parameters. } \\
\text { Blood loss. }\end{array}$ \\
\hline Notes & Follow up was for 3 days. \\
\hline Allocation concealment & B - Unclear \\
\hline
\end{tabular}

\begin{tabular}{|c|c|}
\hline Study & Wahba 1996 \\
\hline Methods & $\begin{array}{l}\text { Randomised controlled trial. Computerised system was used for randomisation. Data on method of allocation } \\
\text { concealment was obtained on contact with the author. } \\
\text { Blinding not mentioned. } \\
\text { Loss to follow up not mentioned. }\end{array}$ \\
\hline Participants & $\begin{array}{l}20 \text { patients who had had coronary artery bypass grafting. Patients with abnormal left-ventricular function as } \\
\text { judged from cine-angiography were excluded as were patients on anticoagulants less than } 10 \text { days before the } \\
\text { operation. }\end{array}$ \\
\hline Interventions & $\begin{array}{l}\text { 1) } 5 \% \text { albumin }(n=10) \\
\text { 2) Haemaccel }(n=10) \\
\text { Number of patients in each group not specified. }\end{array}$ \\
\hline Outcomes & $\begin{array}{l}\text { Haemodynamic variables. } \\
\text { Data on death was obtained on contact with the author. }\end{array}$ \\
\hline$\overline{\text { Notes }}$ & Length of follow up was 2 weeks. \\
\hline Allocation concealment & A - Adequate \\
\hline
\end{tabular}

\begin{tabular}{ll} 
Study & Watkins $\mathbf{1 9 9 0}$ \\
\hline Methods & Randomised controlled trial. No information given on method of randomisation. \\
\hline Participants & 12 patients undergoing major surgery. \\
\hline Interventions & $\begin{array}{l}\text { 1) LMW polystarch or } \\
\text { 2) Polygelatine (Haemaccel) } \\
\text { for postoperative volume replacement. }\end{array}$ \\
\hline Outcomes & Death and incidence of adverse reactions are reported. Detailed complement assay done. \\
\hline Notes & Follow up was for 24 hours after the infusion. \\
\hline Allocation concealment & B - Unclear \\
\hline Colloid solutions for fluid resuscitation (Review) \\
Copyright $\odot \mathbf{2 0 0 7}$ The Cochrane Collaboration. Published by John Wiley \& Sons, Ltd
\end{tabular}




\begin{tabular}{|c|c|}
\hline Study & Woittiez 1997 \\
\hline Methods & $\begin{array}{l}\text { Randomised controlled trial. } \\
\text { Allocation concealment by sequentially numbered sealed opaque envelopes. }\end{array}$ \\
\hline Participants & $\begin{array}{l}60 \text { patients who had developed hypoalbuminaemia }(<20 \mathrm{~g} / \mathrm{l}) \text { after major surgery. } \\
2 \text { patients died after randomisation and before treatment started. These were excluded from the analysis. }\end{array}$ \\
\hline Interventions & $\begin{array}{l}\text { 1) saline }(500 \mathrm{ml} / 24 \mathrm{hr})(\mathrm{n}=16) \text {. } \\
\text { 2) albumin } 20 \%(300 \mathrm{ml} / 24 \mathrm{~h})(\mathrm{n}=15) \text {. } \\
\text { 3) HES } 10 \%(500 \mathrm{ml} / 24 \mathrm{~h}) \text { for } 3 \text { days }(\mathrm{n}=27) \text {. } \\
\text { Aim was to restore colloid osmotic pressure. }\end{array}$ \\
\hline Outcomes & $\begin{array}{l}\text { Changes in fluid balance, serum albumin, COP and clinical signs of oedema were followed daily. } \\
\text { Data on death supplied by the author. }\end{array}$ \\
\hline Notes & Length of follow up unspecified. \\
\hline Allocation concealment & A - Adequate \\
\hline Study & von Sommoggy 1990 \\
\hline Methods & $\begin{array}{l}\text { Randomised controlled trial. No information given on method of randomisation. } \\
\text { No loss to follow up. }\end{array}$ \\
\hline Participants & 24 patients undergoing infrarenal aortofemoral bifurcation grafting. \\
\hline Interventions & $\begin{array}{l}\text { 1) FFP and } 5 \% \text { human albumin }(n=13) \text {. } \\
\text { 2) Hydroxyethyl starch (HES) } 20010 \% \text { and HES } 4506 \% .(n=11) \text {. }\end{array}$ \\
\hline Outcomes & $\begin{array}{l}\text { Haemodynamic variables. } \\
\text { Clotting variables. } \\
\text { Influence on organ function. }\end{array}$ \\
\hline Notes & Follow up 6 hrs post-op. \\
\hline Allocation concealment & B - Unclear \\
\hline $\begin{array}{l}\text { CVP = central venous press } \\
\text { HES = hydroxyethyl starch } \\
\text { HMW = high molecular we } \\
\text { LMW = low molecular weig } \\
\text { LVEDP = left ventricular en } \\
\text { MMW = medium molecula } \\
\text { MAP = mean arterial pressu } \\
\text { PAWP = pulmonary artery } \\
\text { PAOP = pulmonary artery } \\
\text { PCWP = pulmonary capilla }\end{array}$ & $\begin{array}{l}\text { Ire } \\
\text { ight } \\
\text { ht } \\
\text { d diastolic pressure } \\
\text { weight } \\
\text { re } \\
\text { vedge pressure } \\
\text { cclusion pressure } \\
\text { y wedge pressure }\end{array}$ \\
\hline
\end{tabular}

\section{Characteristics of excluded studies}

\begin{tabular}{ll} 
Study & Reason for exclusion \\
\hline Boldt 1993 & Pre-bypass volume loading. \\
\hline Boldt 2000b & Compares two starches with each other. \\
\hline Brehme 1993 & Haemodilution. \\
\hline Bremerich 2000 & Compares two different starches (acetyl starch with hydroxyethyl starch). \\
\hline Charlet 1991 & Study compared two different gelatines with each other and not with other colloids. \\
\hline Christ 1997 & Non-randomised trial. \\
\hline Emery 1992 & Trial compares 20\% and 4.5\% albumin with each other and not with other colloids. \\
\hline Colloid solutions for fluid resuscitation (Review) \\
Copyright @ 2007 The Cochrane Collaboration. Published by John Wiley \& Sons, Ltd
\end{tabular}




\section{Characteristics of excluded studies (Continued)}

Gan 1999 Compares Hextend (a plasma volume expander based upon 6\% hetastarch) with 6\% hetastarch in saline (HES).

\begin{tabular}{ll}
\hline Hankeln 1990 & Haemodilution \\
\hline Harke 1976 & Unable to find out if a randomised controlled trial. Methodology unclear. \\
\hline Hiippala 1996 & Patients were expected to have minimal blood loss \\
\hline Huet 2000 & Compares two starches with each other. \\
\hline Jovanovic 1997 & Does not mention if study was randomised. Unable to contact author for further information. \\
\hline Korttila 1984 & Healthy volunteers and cross over trial. \\
\hline Langeron 2001 & Compares two starches with each other \\
\hline Puri 1983 & $\begin{array}{l}\text { There is no mention of a method of randomisation. Just says “Twenty-five patients studied in each group were well } \\
\text { matched". }\end{array}$ \\
\hline Rauch 2000 & Compares two starches with each other. \\
\hline Rehm 2000 & Haemodilution. \\
\hline Strauss 1985 & Healthy volunteers. \\
\hline Waxman 1989 & Cross-over study. \\
\hline
\end{tabular}

\section{A N A L Y S E S}

\section{Comparison 01. Albumin or PPF vs Hydroxyethyl Starch}

\begin{tabular}{lcclc} 
Outcome title & $\begin{array}{c}\text { No. of } \\
\text { studies }\end{array}$ & $\begin{array}{c}\text { No. of } \\
\text { participants }\end{array}$ & Statistical method & Effect size \\
\hline 01 Death & 20 & 1029 & $\begin{array}{l}\text { Relative Risk (Fixed) } 95 \% \text { CI } \\
\text { Other data }\end{array}$ & $\begin{array}{c}\text { No numeric data } \\
02 \text { Blood/red cells transfused } \\
\text { (skewed or inadequate data) }\end{array}$ \\
\hline
\end{tabular}

\section{Comparison 02. Albumin or PPF vs Gelatin}

\begin{tabular}{lcclc} 
Outcome title & $\begin{array}{c}\text { No. of } \\
\text { studies }\end{array}$ & $\begin{array}{c}\text { No. of } \\
\text { participants }\end{array}$ & Statistical method & Effect size \\
\hline $\begin{array}{l}\text { 01 Death } \\
02 \text { Blood/red cells transfused } \\
\text { (skewed or inadequate data) }\end{array}$ & 4 & 542 & $\begin{array}{l}\text { Relative Risk (Fixed) 95\% CI } \\
\text { Other data }\end{array}$ & $\begin{array}{l}0.99[0.69,1.42] \\
\text { No numeric data }\end{array}$ \\
\hline
\end{tabular}

\section{Comparison 03. Albumin or PPF vs Dextran}

\begin{tabular}{lcccc} 
Outcome title & $\begin{array}{c}\text { No. of } \\
\text { studies }\end{array}$ & $\begin{array}{c}\text { No. of } \\
\text { participants }\end{array}$ & Statistical method & Effect size \\
\hline $\begin{array}{l}\text { 1 Death } \\
02 \text { Blood/red cells transfused } \\
\text { (skewed or inadequate data) }\end{array}$ & 3 & 85 & $\begin{array}{l}\text { Relative Risk (Fixed) } 95 \% \text { CI } \\
\text { Other data }\end{array}$ & $\begin{array}{l}\text { Not estimable } \\
\text { No numeric data }\end{array}$ \\
\hline \hline Colloid solutions for fluid resuscitation (Review) & & 31
\end{tabular}

Copyright ( 2007 The Cochrane Collaboration. Published by John Wiley \& Sons, Ltd 


\section{Comparison 04. Modified Gelatin vs Hydroxyethyl starch}

\begin{tabular}{lcclc} 
Outcome title & $\begin{array}{c}\text { No. of } \\
\text { studies }\end{array}$ & $\begin{array}{c}\text { No. of } \\
\text { participants }\end{array}$ & Statistical method & Effect size \\
\hline 01 Death & 11 & 945 & $\begin{array}{l}\text { Relative Risk (Fixed) } 95 \% \text { CI } \\
\text { Other data }\end{array}$ & $\begin{array}{c}1.00[0.78,1.28] \\
\text { 02 Blood/red cells transfused } \\
\text { (skewed } \text { or inadequate data) }\end{array}$ \\
\hline
\end{tabular}

\section{Comparison 05. Modified Gelatin vs Dextran}

\begin{tabular}{lcclc} 
Outcome title & $\begin{array}{c}\text { No. of } \\
\text { studies }\end{array}$ & $\begin{array}{c}\text { No. of } \\
\text { participants }\end{array}$ & Statistical method & Effect size \\
\hline $\begin{array}{l}\text { 11 Death } \\
\text { 2 Blood/red cells transfused } \\
\text { (skewed or inadequate data) }\end{array}$ & 2 & 42 & $\begin{array}{l}\text { Relative Risk (Fixed) } 95 \% \text { CI } \\
\text { Other data }\end{array}$ & $\begin{array}{l}\text { Not estimable } \\
\text { No numeric data }\end{array}$ \\
\hline
\end{tabular}

Comparison 06. Hydroxyethyl starch vs Dextran

\begin{tabular}{|c|c|c|c|c|}
\hline Outcome title & $\begin{array}{l}\text { No. of } \\
\text { studies }\end{array}$ & $\begin{array}{c}\text { No. of } \\
\text { participants }\end{array}$ & Statistical method & Effect size \\
\hline 01 Death & 0 & 0 & Relative Risk (Fixed) 95\% CI & Not estimable \\
\hline $\begin{array}{l}02 \text { Blood/red cells transfused } \\
\text { (skewed or inadequate data) }\end{array}$ & & & Other data & No numeric data \\
\hline
\end{tabular}

\section{NDEX TERMS}

\section{Medical Subject Headings (MeSH)}

Blood Proteins [*therapeutic use]; Colloids [therapeutic use]; Dextrans [*therapeutic use]; *Fluid Therapy; Plasma Substitutes [*therapeutic use]; Randomized Controlled Trials; Rehydration Solutions [*therapeutic use]

MeSH check words

Humans

\section{COVER SHEET}

Title

Authors

\section{Contribution of author(s)}

Issue protocol first published

Review first published

Date of most recent amendment

Date of most recent SUBSTANTIVE amendment

\section{Colloid solutions for fluid resuscitation}

\section{Bunn F, Alderson P, Hawkins V}

FB screened citations for eligibility, obtained references, contacted authors, extracted data, entered data and wrote up the review. PA screened citations for eligibility, extracted data and helped to write the review. VH obtained references, contacted authors, extracted data and helped to write the review. FB and PA updated the review.

$1998 / 4$

$1999 / 2$

18 August 2003

17 September 2002

The search for the review was updated in September 2002 and five new studies were added to the review. The five new studies all compared gelatin to starch. 
Date new studies sought but none found

Date new studies found but not yet included/excluded

Date new studies found and included/excluded

Date authors' conclusions section amended

Contact address

DOI

Cochrane Library number

Editorial group

Editorial group code
Information not supplied by author

Information not supplied by author

17 September 2002

Information not supplied by author

Ms Frances Bunn

Research Fellow

Centre for Research in Primary and Community Care (CRIPACC)

University of Hertfordshire

College Lane

Hatfield

Hertfordshire

AL10 9PN

UK

E-mail: f.bunn@herts.ac.uk

Tel: 01707286457

10.1002/14651858.CD001319

CD001319

Cochrane Injuries Group

HM-INJ

GRAPHS ANDOTHER TABLES 


\section{Analysis 0I.0I. Comparison 0I Albumin or PPF vs Hydroxyethyl Starch, Outcome 0I Death}

Review: Colloid solutions for fluid resuscitation

Comparison: Ol Albumin or PPF vs Hydroxyethyl Starch

Outcome: 01 Death

\begin{tabular}{|c|c|c|c|c|c|c|}
\hline \multirow{2}{*}{\multicolumn{2}{|c|}{ Study }} & Albumin or PPF & Hydroxyethyl starch & \multirow{2}{*}{$\begin{array}{l}\text { Relative Risk (Fixed) } \\
95 \% \mathrm{Cl}\end{array}$} & \multirow{2}{*}{$\begin{array}{c}\text { Weight } \\
(\%)\end{array}$} & \multirow{2}{*}{$\begin{array}{c}\text { Relative Risk (Fixed) } \\
95 \% \mathrm{Cl}\end{array}$} \\
\hline & & $\mathrm{n} / \mathrm{N}$ & $\mathrm{n} / \mathrm{N}$ & & & \\
\hline & Boldt 1995 & $6 / 30$ & $5 / 30$ & & 6.4 & $1.20[0.41,3.5 \mid]$ \\
\hline & Boldt 1996 A & $9 / 30$ & $7 / 30$ & & 8.9 & $1.29[0.55,3.00]$ \\
\hline & Boldt 1996 B & $2 / 15$ & $1 / 15$ & & 1.3 & $2.00[0.20,19.78]$ \\
\hline & Boldt 1996 C & $10 / 28$ & $9 / 28$ & & 11.4 & I.II $[0.53,2.31]$ \\
\hline & Boldt 1998 & $39 / 150$ & $31 / 150$ & & 39.4 & $1.26[0.83,1.90]$ \\
\hline$x$ & Brock 1995 & $0 / 7$ & $0 / 14$ & & 0.0 & Not estimable \\
\hline$\times$ & Brutocao 1996 & $0 / 18$ & $0 / 20$ & & 0.0 & Not estimable \\
\hline$\times$ & Diehl 1982 & $0 / 33$ & $0 / 27$ & & 0.0 & Not estimable \\
\hline$x$ & Gallagher 1985 & $0 / 5$ & $0 / 5$ & & 0.0 & Not estimable \\
\hline$x$ & Gold 1990 & $0 / 20$ & $0 / 20$ & & 0.0 & Not estimable \\
\hline$x$ & Kirklin 1984 & $0 / 15$ & $0 / 15$ & & 0.0 & Not estimable \\
\hline & London 1989 & $1 / 44$ & $2 / 50$ & & 2.4 & $0.57[0.05,6.05]$ \\
\hline$\times$ & Mastroianni 1994 & $0 / 18$ & $0 / 16$ & & 0.0 & Not estimable \\
\hline$x$ & Munsch 1988 & $0 / 20$ & $0 / 20$ & & 0.0 & Not estimable \\
\hline & Prien 1990 & $0 / 6$ & $1 / 6$ & & 1.9 & $0.33[0.02,6.86]$ \\
\hline & Rackow 1983 & $6 / 9$ & $5 / 9$ & & 6.4 & $1.20[0.57,2.53]$ \\
\hline & Rackow 1989 & $5 / 10$ & $5 / 10$ & & 6.4 & $1.00[0.42,2.40]$ \\
\hline$\times$ & Rosencher 1992 & $0 / 16$ & $0 / 16$ & & 0.0 & Not estimable \\
\hline & Shatney 1983 & $3 / 16$ & $3 / 16$ & & 3.8 & $1.00[0.24,4.23]$ \\
\hline & Woittiez 1997 & $8 / 15$ & $13 / 27$ & 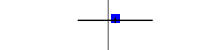 & 11.8 & I.II [0.60, 2.05$]$ \\
\hline & tal $(95 \% \mathrm{Cl})$ & 505 & 524 & - & 100.0 & $1.17[0.91,1.50]$ \\
\hline \multicolumn{7}{|c|}{ Total events: 89 (Albumin or PPF), 82 (Hydroxyethyl starch) } \\
\hline \multicolumn{7}{|c|}{ Test for heterogeneity chi-square $=1.62 \mathrm{df}=10 \mathrm{p}=1.00 \mathrm{I}^{2}=0.0 \%$} \\
\hline & est for overall effect $z=$ & $p=0.2$ & & & & \\
\hline
\end{tabular}

$\begin{array}{lllllll}0.1 & 0.2 & 0.5 & 1 & 2 & 5 & 10\end{array}$

Albumin or PPF Hydroxyethyl starch

Analysis 01.02. Comparison 0I Albumin or PPF vs Hydroxyethyl Starch, Outcome 02 Blood/red cells transfused (skewed or inadequate data) 


\section{Blood/red cells transfused (skewed or inadequate data) \\ Study}

Boldt 1998

Brock 1995

\section{Brock 1995}

Brutocao 1996

Claes 1992

Diehl 1982

Falk 1988

Gallagher 1985

Gold 1990

Hiippala 1995

Kirklin 1984

London 1989

Mastroianni 1994

Moggio 1983

Munsch 1988

Prien 1990

Rackow 1983

Rackow 1989

Shatney 1983

Vogt 1994 medians or measures of variation given.

Total units of red blood cells transfused given for each group (Hetastarch 356, albumin 371). No means, The amount of blood derivaties ('blutderivate') was given in $\mathrm{ml}$ as a mean and standard deviation. In the $10 \%$ starch group the mean was 379 (SD483), in the 6\% starch group the mean was 243 (SD 192) and in the 5\% albumin group the mean was 171 (SD236).

Packed red cell transfusion is given in $\mathrm{ml} / \mathrm{kg}$. In the HES group the mean is 0.3 , the SD 1.3 with a range of 0 6.4. In the albumin group the mean is 1.1 the SD 3.7 and the range $0-13.1$

Blood transfused is not recorded. Authors say "none of the patients lost an abnormally large quantity of blood or experienced a clinically perceptible coagulation disorder."

Eighteen percent $(n=5)$ of the albumin group and $15 \%(n=5)$ of the HES group received banked blood during their stay. Blood transfused is recorded as mean number of units per person. In the albumin group this is 0.37 unit per person and in the HES group this is 0.36 unit per person.

Packed red blood cells transfused at 24 hours is given in mls. The albumin group received a mean of 375 with a standard error of 244 and the HES group received a mean of 700 with a standard error of 228.

Amount of blood products transfused post operatively was given as a mean in mls with the SEM. For the albumin group the mean was $560 \mathrm{mls}$ (SEM 149.2) and for the starch group the mean was $566 \mathrm{mls}$ (SEM 72.6).

Packed red blood cells is given in units. The albumin group received a mean of 2.05 and the HES group received a mean of 2.50 .

Amount of red cell concentrates transfused was given as a mean and standard deviation of $\mathrm{ml} / \mathrm{kgBW}$. For albumin the mean was 20 (SD 14), for 4\% HES the mean was 20 (SD 14) and for 6\% HES the mean was 25 (SD 17).

The amount of red cells given up to the first 24 hours post op is recorded. In the HES group the mean is 430 with a standard error of 90 , and in the albumin group the mean is 440 with a standard error of 76

Total post op blood transfused is given in mls. in the Albumin group the figures are given as 838 (630) and the HES group 894 (600). It does not report what the figures represent (they may be mean and SD). Intraoperatively the blood given in the albumin group was 400 (346) and in the HES group 336 (400).

The mean of packed red cells given was recorded in mls. For pentastarch the mean was 167 and for albumin it was 234. Another figure was given 163 for pentasarch and 148 for albumin but it was not clear what this represented.

There was no data on amount of blood transfused.

amount of whole blood transfused was given as a median volume. For the albumin group it was $830 \mathrm{mls}$ (2601800), and for the HES group it was $830 \mathrm{mls} \mathrm{(50-1840).}$

The mean and standard error for the amount of packed red cells given was recorded. For the albumin group the mean was 1.2 with a standard error of 0.7 . In the HES group the mean was 1.8 with a standard error of 0.7 .

Total amount of blood transfused was given in mls at the end of the maintenance period. For the albumin group the mean was 363.9 (SEM 186) and for the starch group the mean was 757.1 (SEM 201).

No data on units transfused. The authors say "there was no evidence of clinical bleeding".

The amount of red blood cells transfused was given in a graphical form not figures.

Amount of EK given was recorded as a mean and standard deviation of the mls given. For the albumin group it was 1138 (SD 763.5), and for the HES group it was 944.4 (SD 466.2). 

6 hours. For the albumin group at the end of surgery the mean was 798 (SD 1147) and at 6 hrs it was 1333 (SD 1399). For the HES group at the end of surgery the mean was 763 (SD 923), and at 6 hrs the mean was 1538 (SD 1074).

Vogt 1999 During surgery the patients in the HES group Amount of packed red blood cells was given as means with standard deviations. In the HES grp the mean was $1510 \mathrm{ml}$ (SD 765) and in the albumin group the mean was $1410 \mathrm{ml}$ (SD 946)

von Sommoggy 1990 The trialists report 'no increased bleeding in the HES group'.

\section{Analysis 02.01. Comparison 02 Albumin or PPF vs Gelatin, Outcome 01 Death}

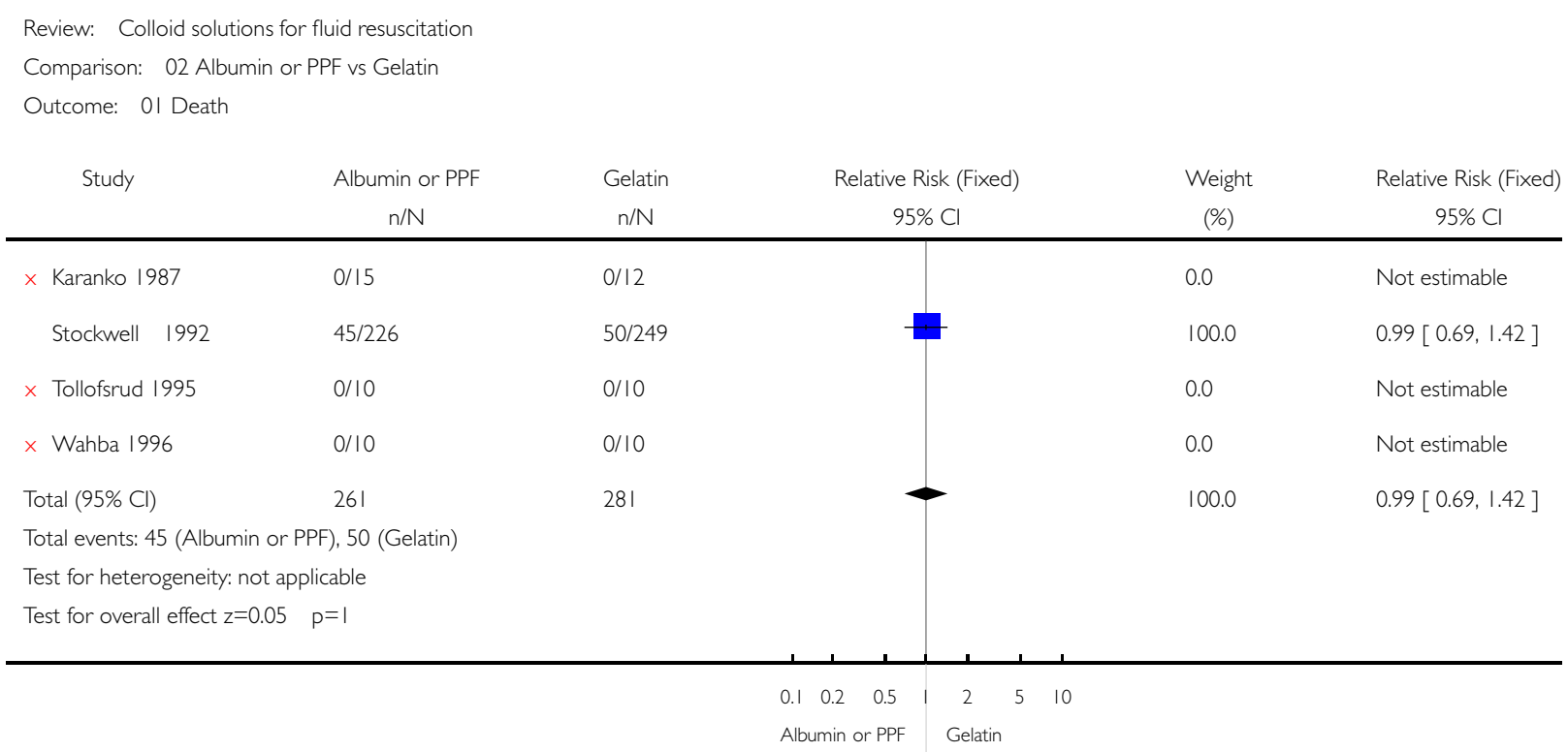

\section{Analysis 02.02. Comparison 02 Albumin or PPF vs Gelatin, Outcome 02 Blood/red cells transfused (skewed or inadequate data)}

\section{Blood/red cells transfused (skewed or inadequate data) \\ Study}

Stockwell 1992 The volume of blood products given was recorded as a mean with the range also given. In the albumin group the mean was 1.451 (range $10-29$ ) and in the haemacell group the mean was 1.391 (range 0-66).

Tollofsrud 1995 The amount of erthrocytes given was recorded as a mean and standard deviation. In the albumin group the mean was 240 (SD 310), and in the polygeline group the mean was 490 (SD 548). 


\section{Analysis 03.01. Comparison 03 Albumin or PPF vs Dextran, Outcome 0I Death}

Review: Colloid solutions for fluid resuscitation

Comparison: 03 Albumin or PPF vs Dextran

Outcome: 01 Death

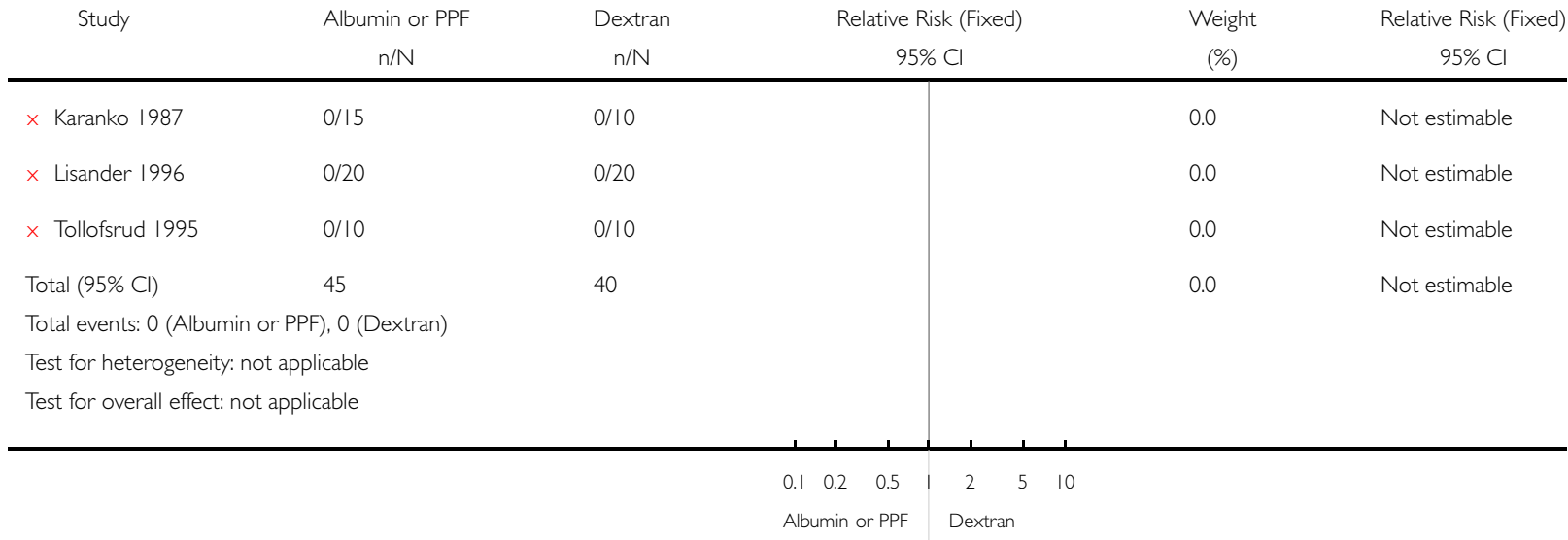

\section{Analysis 03.02. Comparison 03 Albumin or PPF vs Dextran, Outcome 02 Blood/red cells transfused (skewed or inadequate data)}

\section{Blood/red cells transfused (skewed or inadequate data)}

Study

Hedstrand 1987 The perioperative and postoperative amount of red blood cells transfused was reported as a mean and standard deviation of units given. For the plasma group the mean was 5.2 (SD 4.8), and for the dextran group the mean was 5.8 (SD 4.4).

Hiippala 1995 Amount of red cell concentrates transfused was given as a mean and standard deviation of $\mathrm{ml} / \mathrm{kgBW}$. For albumin the mean was 20 (SD 14) and for dextran the mean was 19 (12).

Lisander 1996 Total red blood cells transfused is given. For the albumin group the mean is 2.3 and the standard deviation 1.6, in the Dextran group the mean is 3.8 with a standard deviation of 2.4. Red cells autotransfused is also given 312 (184) in the albumin group and 383 (259) in the dextran group.

Tollofsrud 1995 Erythrocytes given was recorded as mean and standard deviation. The mean for the albumin group was 240 (SD 310 ), and the mean for the dextran group was 390 (SD 417). 


\section{Analysis 04.0I. Comparison 04 Modified Gelatin vs Hydroxyethyl starch, Outcome 0I Death}

Review: Colloid solutions for fluid resuscitation

Comparison: 04 Modified Gelatin vs Hydroxyethyl starch

Outcome: 01 Death

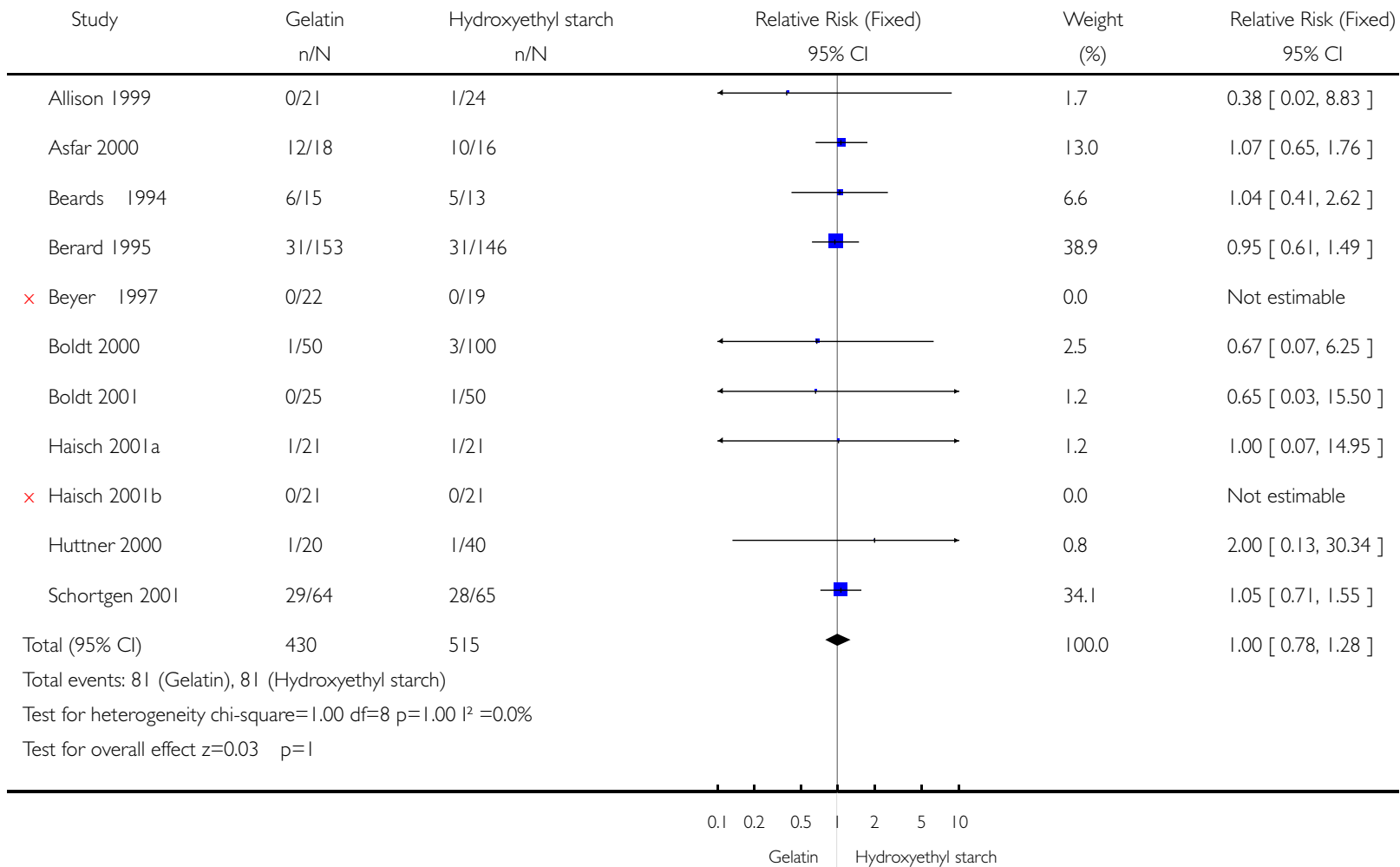

\section{Analysis 04.02. Comparison 04 Modified Gelatin vs Hydroxyethyl starch, Outcome 02 Blood/red cells transfused (skewed or inadequate data)}

\section{Blood/red cells transfused (skewed or inadequate data)}

Study

Allison 1999 The mean volume of PRBC transfused is given for each day up to and including the 5th day. For the first post-op day the HES group received a total of 3,067 $\mathrm{ml}$ of packed red blood cells and the Gelatine group received 2,643 $\mathrm{ml}$ of packed red blood cells.

Berard 1995 Blood transfused is given in units, 2.6 units for the gel group and 2.5 units for the Hydroxyethyl starch group (presumably this figure is mean).

Beyer 1997 Blood transfused is given in graphical form and not figures.

Boldt 2000 The amount of PRBC transfused is given as the total number of units for each group.

By the first post operative day the number of units of packed red blood cells transfused was:

HES 70 - 38 units

HES 200 - 40 units

Gelatin - 44 units

Boldt 2001 The amount of PRBC transfused is given as the total number of units for each group. 


\section{Blood/red cells transfused (skewed or inadequate data) (Continued)}

Study

By the first post operative day the number of units of packed red blood cells transfused was:

HES 20018 units

HES 13016 units

Gelatin 18 units

Carli 2000 The amount of PRBC transfused is given as the total number of units for each group.

1 unit of blood was given in the gel group and no units of blood were given in the starch group.

Haisch 2001a The amount of PRBC and FFP transfused is given as the total number of units for each group. PRBC

Gelatine $=16$ units

Starch $=20$ units

FFP

Gelatin $=6$

Starch $=8$

Haisch 2001b The amount of PRBC and FFP transfused is given as the total number of units for each group. PRBC

Gelatin $=17$

Starch $=14$

FFP

Gelatin $=12$

Starch $=12$

Huttner 2000 The amount of PRBC transfused is given as the total number of units for each group. Units of PRBC were as follows:

HES 51

Gelatin 29

Analysis 05.01. Comparison 05 Modified Gelatin vs Dextran, Outcome 0 I Death

Review: Colloid solutions for fluid resuscitation

Comparison: 05 Modified Gelatin vs Dextran

Outcome: 0 I Death

\begin{tabular}{|c|c|c|c|c|c|}
\hline Study & $\begin{array}{c}\text { Gelatin } \\
n / N\end{array}$ & $\begin{array}{c}\text { Dextran } \\
\mathrm{n} / \mathrm{N}\end{array}$ & $\begin{array}{c}\text { Relative Risk (Fixed) } \\
\quad 95 \% \mathrm{Cl}\end{array}$ & $\begin{array}{c}\text { Weight } \\
(\%)\end{array}$ & $\begin{array}{l}\text { Relative Risk (Fixed } \\
\qquad 95 \% \mathrm{Cl}\end{array}$ \\
\hline × Karanko 1987 & $0 / 12$ & $0 / 10$ & & 0.0 & Not estimable \\
\hline × Tollofsrud 1995 & $0 / 10$ & $0 / 10$ & & 0.0 & Not estimable \\
\hline Total $(95 \%$ Cl) & 22 & 20 & & 0.0 & Not estimable \\
\hline \multicolumn{6}{|c|}{ Total events: 0 (Gelatin), 0 (Dextran) } \\
\hline \multicolumn{6}{|c|}{ Test for heterogeneity: not applicable } \\
\hline Test for overall effec & & & & & \\
\hline
\end{tabular}


Analysis 05.02. Comparison 05 Modified Gelatin vs Dextran, Outcome 02 Blood/red cells transfused (skewed or inadequate data)

Blood/red cells transfused (skewed or inadequate data)

Study

Tollofsrud 1995 Erythrocytes given was recorded as mean and standard deviation. The mean in the polygeline group was 490 (SD 548), and the mean in the dextran group was 390 (SD 417).

\section{Analysis 06.02. Comparison 06 Hydroxyethyl starch vs Dextran, Outcome 02 Blood/red cells transfused (skewed or inadequate data)}

Blood/red cells transfused (skewed or inadequate data)

Study

Hiippala 1995 Amount of red cell concentrates transfused was given as a mean and standard deviation of $\mathrm{ml} / \mathrm{kgBW}$. For dextran the mean was 19 (SD 12), for $4 \%$ starch the mean was 20 (SD 14) and for 6\% starch the mean was 25 (SD 17). 